\title{
Gene therapy. The legacy of Wacław Szybalski*
}

\author{
Józef Dulak \\ Department of Medical Biotechnology, Faculty of Biochemistry, Biophysics and Biotechnology, Jagiellonian University, Kraków, Poland
}

Seminal demonstration of the possibility of stable genetic modification of mammalian cells performed by Wacław and Elisabeth Szybalski opened the doors for gene therapy, the term coined by Wacław Szybalski already in 1962. In the next 60 years, numerous tools for gene delivery have been developed and applied for clinical research, culminating in the registration of several genetic therapies in Europe and the USA. Some of these strategies, aimed to treat severe combined immunodeficiencies, inherited forms of blindness, spinal muscular atrophy, some cancers, and genetic anemias, are the real hope for patients suffering from previously incurable diseases or the ones whose treatment was not effective. On the approaching 60th anniversary of gene therapy, combined with the 100th anniversary of the birth of Professor Wacław Szybalski (September 9th, 1921), who passed away on December 16, 2020, here I present the summary of the most important aspects of clinical applications of genetic therapies.

Keywords: retroviral vectors, self-inactivating lentiviral vectors, AAV vectors, adenoviral vectors, CRISPR/Cas9, gene editing, Duchenne muscular dystrophy, spinal muscular atrophy, severe combined immunodeficiencies, $\beta$-thalassemia, sickle cell anemia, CAR-T, antisense oligonucleotides, siRNA

Received: 29 July, 2021; revised: 31 July, 2021; accepted: 31 July, 2021; available on-line: 31 August, 2021

घe-mail: jozef.dulak@uj.edu.pl

* This paper is dedicated to the memory of Professor Wacław Szybalski and Professor Anna Podhajska, whom I had the honor to meet for the first time in 1994 and who have been instrumental in developing my interest in medical biotechnology, and especially in gene therapy.

Acknowledgements of Financial Support: Financial support: MAESTRO 10 grant (2018/30/A/NZ3/00412) from the National Science Center (NCN), CISTEM MSCA RISE (Z/H2O/00023) from the H2020 program (grant agreement No. 778354), and NMJ-on-a-chip (UMO-2019/01/Y/NZ3/00012) from the JPND initiative (Horizon 2020) and NCN.

Abbreviations: AAV, adeno-associated viruses; ADA-PEG, adenosine deaminase-polyethylene glycol; ADA-SCID, adenosine deaminase-severe combined immunodeficiency syndrome; AIDS, acquired immunodeficiency syndrome; ALD, adrenoleukodystrophy; ALL, acute lymphoblastic leukemia; a-Gal, a-galactosidase A; BCLA11A, BAF Chromatin Remodeling Complex Subunit BCL11A.; $B C M A, B-c e l l$ maturation antigen; CAR, chimeric antigen receptor; CAR-T cells, chimeric antigen receptor T cells; CCR5, C-C chemokine receptor type 5; CDNA, complementary DNA; CD4, cluster of differentiation 4; CD19, cluster of differentiation 19; CD34, cluster of differentiation 34; CEP290, centrosomal protein 290; CGD, chronic granulomatous disease; c-Myc, c-Myc oncogene; COVID-19, coronavirus disease 2019; CRISPR/Cas9, clustered regulated interspaced short palindromic repeats/CRISPR-associated 9; CSF3, colony stimulating factor 3; DMD, Duchenne muscular dystrophy; DNA, deoxyribonucleic acid; EB, epidermolysis bullosa; EMA, European Medicines Agency; ESC, embryonic stem cells; FDA, Food and Drug Administration; GM, glioblastoma multiforme; HAT medium, hypoxantine-aminopterin-thymidine medium; hATTR, hereditary transthyretin-mediated amyloidosis; HEK293 cells, human embryonic kidney 293 cells; HIV, human immunodeficiency virus; hNRNP-A1, heterogeneous nuclear ribonucleoprotein A1; HPRT, hypoxanthineguanine phosphoribosyl transferase; HR, homologous recombina- tion; HSC, hematopoietic stem cells; HSPC, hematopoietic stem and progenitor cells; HSV1-GM-CSF, herpes virus 1-granulocyte macrophage-colony stimulating factor; HSV-TK, herpes virus thymidine kinase; iPSC, induced pluripotent stem cells; ITR, inverted terminal repeats; KIf4, Kruppel-like factor 4; LAMB3, Laminin Subunit Beta 3. LCA, Lebers' congenital amaurosis; LMO2, LIM domain only 2; LPL, lipoprotein lipase; LPLD, lipoprotein lipase deficiency; LSD, lisosomal storage disease; MDS1/EVI1, MDS1 and EVI1 complex locus; mRNA, messenger ribonucleic acid; NHEJ, non-homologous end joining; $\mathrm{NIH}$, National Institute of Health; NMJ, neuromuscular junctions; Oct4, octamer-binding transcription factor 4; OTC, ornithine transcarbamylase; RGD, arginine, glycine and aspartate; RNA, ribonucleic acid; RPE65, retinal pigment epithelium 65 gene SARS-Cov-2, severe acute respiratory syndrome coronavirus 2; SCD, sickle cell disease; sgRNA, single guide RNA; siRNA, small interfering RNA; SMA, spinal muscular atrophy; SMN, survival motor neuron; Sox2, SRY (sex determining region Y)-box 2; TALEN, transcription activator-like effector nuclease; Tet-off/Tet-on, tetracycline-off/ tetracycline-on; TK, thymidine kinase; U1-snRNP, U1 spliceosomal small nuclear RNA protein; VSV, vesicular stomatitis virus; X-SCID, $X$ (chromosome) -linked-severe combined immunodeficiency syndrome; ZFN, zinc finger nuclease; ZFP, zinc finger protein

\section{INTRODUCTION}

Traditionally, gene therapy is considered as the treatment of diseases caused by a defined genetic mutation, which can be overcomed by restoration of expression of the correct version of a gene. Nevertheless, the idea of gene therapy has very much evolved from the original definition. While the replacement therapy, i.e. introducing the non-mutated version of the gene to substitute the faulty one, is still the bona fide gene therapy, one has to be aware that the genetic approaches, which are targeted at the molecular background of the diseases and employ the genetic strategies or nucleic acids as the medicines, are currently much more diverse. Hence, the dogmatic view on gene therapy is no longer valid, and the statement that only replacement gene therapy represents the original one is unjustified, similarly to the belief that one gene encodes one protein. We are now fully aware of the complexity of the gene structure, but this does not abolish the validity and importance of the original "one gene - one protein" hypothesis. Similarly, the founding statements that gene therapy is about restoring the proper version of the gene does not mean that it is limited only to such an approach.

Gene transfer with engineered vectors became a routine tool for research and is applied in numerous experimental therapies in animal models. According to the Gene Therapy Clinical Trials Worldwide Journal of Gene Medicine site - GTCT (FMS19) (fmphost. com)), up to this year, 3180 clinical trials of gene therapy have been performed, with more than 800 gene therapy trials ongoing in clinical development (High \& Roncarolo, 2019). The first officially approved clinical trial of gene therapy has been performed in 1991, and up to date six gene therapies have been registered in Europe and the USA (Table 1). This number comprises classical 
Table 1. Genetic therapies registered by EMA and/or FDA and the mode of their actions (vaccines not included) (as of July 2021) (Brand name first)

\begin{tabular}{|c|c|c|c|c|c|c|}
\hline \multirow[t]{2}{*}{$\begin{array}{l}\text { In vivo delivery of } \\
\text { correct version of } \\
\text { mutated gene }\end{array}$} & \multirow[t]{2}{*}{$\begin{array}{l}\text { Ex vivo gene } \\
\text { replacement in } \\
\text { stem/progenitor } \\
\text { cells }\end{array}$} & \multirow[t]{2}{*}{$\begin{array}{l}\text { Ex vivo engineering } \\
\text { of T-lymphocytes for } \\
\text { anti-cancer therapies } \\
\text { (CAR-T therapies) }\end{array}$} & \multirow[t]{2}{*}{$\begin{array}{l}\text { Oncolytic vi- } \\
\text { ruses }\end{array}$} & \multicolumn{3}{|c|}{$\begin{array}{l}\text { Antisense oligonucleotides/siRNAs for gene inhibi- } \\
\text { tion or gene repair } \\
\text { (siRNA - names ends with: ran; DNA oligos - en) }\end{array}$} \\
\hline & & & & $\begin{array}{l}\text { Inhibition of } \\
\text { mRNA expression }\end{array}$ & $\begin{array}{l}\text { Exon inclu- } \\
\text { sion }\end{array}$ & Exon skipping \\
\hline $\begin{array}{l}\text { Glybera (alipogene } \\
\text { tiparvovec) } \\
\text { Luxturna (voretige- } \\
\text { ne neparvovec-rzyl) } \\
\text { Zolgensma (ona- } \\
\text { semnogene abepar- } \\
\text { wowec) }\end{array}$ & $\begin{array}{l}\text { Strimvelis } \\
\text { Zynteglo (beti- } \\
\text { beglogene auto- } \\
\text { temcel) } \\
\text { Limbeldy (ati- } \\
\text { darsagene auto- } \\
\text { temcel) }\end{array}$ & $\begin{array}{l}\text { Kymriah (tisagenlec- } \\
\text { leucel) } \\
\text { Yescarta (axicabtage- } \\
\text { ne ciloleucel) } \\
\text { Tecartus (brexucabta- } \\
\text { gene autoleucel) } \\
\text { Abecma (idecabtage- } \\
\text { ne vicleucel) } \\
\text { Breyanzi (lisocabtage- } \\
\text { ne maraleucel) }\end{array}$ & $\begin{array}{l}\text { Imlygic (Talimo- } \\
\text { gene laherpare- } \\
\text { pvec; T-VEC) }\end{array}$ & $\begin{array}{l}\text { Onpattro (pati- } \\
\text { saran) Tegsedi } \\
\text { (inotersen) } \\
\text { Givlaari (givosiran) } \\
\text { Leqvio (inclisiran) } \\
\text { Oxlumo (luma- } \\
\text { siran) }\end{array}$ & $\begin{array}{l}\text { Spinraza (nu- } \\
\text { sinersen) }\end{array}$ & $\begin{array}{l}\text { Exondys } 51 \\
\text { (eteplirsen) } \\
\text { Vyondys } 53 \\
\text { (golodirsen) } \\
\text { Viltepso (vito- } \\
\text { larsen) } \\
\text { Amnodys } 45 \\
\text { (casimersen) }\end{array}$ \\
\hline
\end{tabular}

gene therapies in which the correct versions of mutated genes are introduced into the patients either directly, by an in vivo approach, or the disease is treated by an ex vivo modification of stem or progenitor cells which are then infused back into the patient. Nevertheless, numerous research has led in fact to development and registration of more than 20 genetic therapies in which nucleic acids are used to cure the diseases (Table 1). This is exemplified by modification of T-lymphocytes to improve their elimantion of cancer cells (CAR-T cell therapies) (Ellis et al., 2021), and the application of siRNA or antisense oligonucleotides to remove the mutated nucleic acid, or antisense oligonucletotides to repair the mutation by exon skipping or exon inclusion (for review see: Winkle et al., 2021). In a much broader sense, genetic therapies also involve application of the coding mRNA sequences, which in the last year became famous thanks to the development of $\mathrm{mRNA}$ vaccines against SARS-CoV-2. The same concerns also DNA-based (adenoviral) anti-SARSCov-2 vaccines.

\section{GENE DELIVERY TOOLS}

When Wacław and Elizabeth Szybalski performed the first effective genetic modification of mammalian cells, they have used DNA isolated from healthy cells and introduced it into cells lacking the hypoxanthine-guanine phosphoribosyl transferase (HPRT) enzyme (Szybalska \& Szybalski, 1962). Such cells were not able to grow in the HAT medium, designed by them, which contains hypoxanthine, aminopterin, and thymidine. The HPRTdevoid cells die in the HAT medium, because aminop-

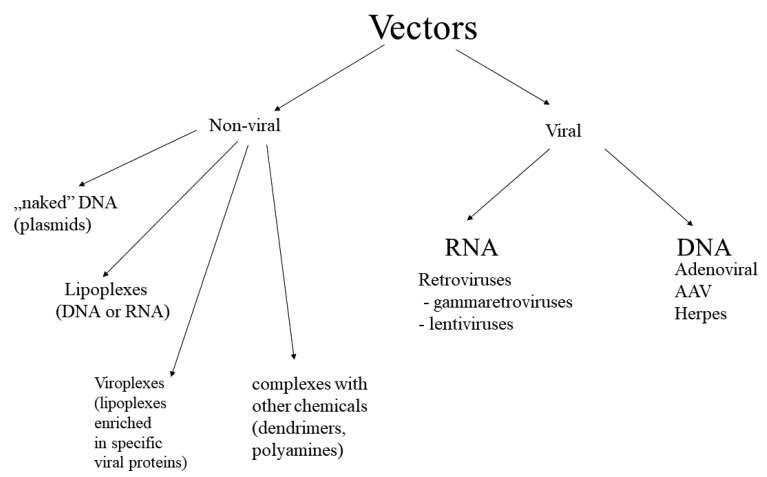

Figure 1. Major modes of gene delivery used in clinical gene therapies terin blocks de novo synthesis of nucleic acids, while the lack of HPRT prevents the compensatory action of the salvage pathway of nucleotide synthesis, in which they are synthesized by HPRT and thymidine kinase from hypoxanthine and thymidine, respectively. The Szybalski's approach was brilliant, but concomitantly very straightforward because at the time of their work they did not know the uncountable complexities of gene delivery and the barriers hindering effective genetic modification of the cells. According to the current knowledge, Szybalski's experiment was even destined to failure, because the free nucleic acid is negatively charged and cannot normally enter (as the so-called naked DNA) into the mammalian cells due to the negatively charged cell membrane and other barriers, like extracellular matrix. Currently, we apply various positively charged molecules, such as cationic liposomes, polyamines, and dendrimers which neutralize the negative charge of DNA and change it to a positive one, which allows the DNA or RNA to enter into the cells (Fig. 1) (for review see: Belmadi et al., 2015). Nevertheless, the successful modification achieved by Szybalski was possible thanks to the high concentration of calcium ions used for DNA precipitation, which neutralized the negative charge of DNA (Prof. Wacław Szybalski: personal communication).

The idea of gene therapy as a way to introduce the correct version of the mutated gene for the treatment of diseases was then coined by Wacław Szybalski and proposed at a series of conferences (for references see: Szybalski, 2013). The sixties and seventies of the former century were the time of development of various tools to modify the cells, with the application of calcium chloride and dextran sulfate as the effective methods for gene delivery (Table 2). They were, however, impractical from the point of in vivo gene transfer. The beginning of genetic engineering, initiated by the discovery of restriction enzymes and ligases, allowing manipulation of nucleic acids through cutting and joining various sequences, led to the applications of plasmid vectors for the delivery of genes to mammalian cells. Nevertheless, an efficient genetic modification of mammalian cells and its application in vivo became possible only when the knowledge on the structure and biology of viruses allowed their modification to use them as safe viral vectors (for review see: (Wirth et al., 2013)) (Fig. 1).

\section{VIRAL VECTORS}

Viral vectors are the most commonly used tools for gene therapy, with the retroviral/lentiviral, adenoviral, 
Table 2. Some major milestones and achievements in gene therapy

\begin{tabular}{|c|c|c|c|}
\hline Year & Milestone/achievement & Who/where & Comments \\
\hline 1962 & $\begin{array}{l}\text { First effective modification of } \\
\text { mammalian cells by delivery } \\
\text { of DNA from healthy cells }\end{array}$ & $\begin{array}{l}\text { Wacław and Elisabeth Szy- } \\
\text { balski }\end{array}$ & $\begin{array}{l}\text { HPRT-lacking cells were successfully transfected } \\
\text { thanks to the high concentration of calcium ions } \\
\text { in the media }\end{array}$ \\
\hline 1970s-1990s & $\begin{array}{l}\text { Calcium phosphate, liposo- } \\
\text { mes, dendrimers for trans- } \\
\text { fection of non-viral vectors } \\
\text { (plasmids) }\end{array}$ & Many researchers & $\begin{array}{l}\text { Effective for in vitro delivery; liposomes are also } \\
\text { currently used for the delivery of mRNA based } \\
\text { anti-SARS-COV-2 vaccines }\end{array}$ \\
\hline 1970s-1990s & $\begin{array}{l}\text { Genetic engineering - plasmid } \\
\text { vectors used for gene transfer; } \\
\text { manipulation of retroviral, } \\
\text { adenoviral, and AAV vectors }\end{array}$ & Many researchers & $\begin{array}{l}\text { Development of packaging cells (such as HEK293) } \\
\text { allowed efficient production of high titer vectors; } \\
\text { usage of naturally occurring serotypes and genetic } \\
\text { manipulation permits targeting vectors to diffe- } \\
\text { rent cell types; problems exist with the immune } \\
\text { response to vectors due to pre-existing antibodies; } \\
\text { problems with insertional mutagenesis in case of } \\
\text { retroviral vectors }\end{array}$ \\
\hline
\end{tabular}

\begin{tabular}{|c|c|c|c|}
\hline 1989 & $\begin{array}{l}\text { Retroviral vector's first modifi- } \\
\text { cation of patients' cells }\end{array}$ & $\begin{array}{l}\text { Steven Rosenberg et al. NIH } \\
\text { Bethesda, USA }\end{array}$ & $\begin{array}{l}\text { Terminally sick melanoma patients received an } \\
\text { infusion of autologous leukocytes transduced with } \\
\text { the retroviral vector }\end{array}$ \\
\hline 1991 & $\begin{array}{l}\text { First gene therapy trial - ADA- } \\
\text {-SCID }\end{array}$ & $\begin{array}{l}\text { Michael Blaese et al, NIH } \\
\text { Bethesda, USA }\end{array}$ & $\begin{array}{l}\text { Patients received genetically modified lymphocytes } \\
\text { in addition to ADA-PEG }\end{array}$ \\
\hline 1999 & $\begin{array}{l}\text { Death of Jesse Gelssinger in } \\
\text { the clinical trial of gene thera- } \\
\text { py for ornithine transcarbamy- } \\
\text { lase deficiency }\end{array}$ & Philadelphia, USA & $\begin{array}{l}\text { This death was due to the pre-existing immunity } \\
\text { to adenoviruses which aggravated when large } \\
\text { doses of adenoviral vector were injected into the } \\
\text { patient }\end{array}$ \\
\hline 2000 & $\begin{array}{l}\text { First successful retroviral gene } \\
\text { therapy of X-SCID }\end{array}$ & $\begin{array}{l}\text { Marina Cavazanna-Calvo \& } \\
\text { Alain Fischer, Paris }\end{array}$ & $\begin{array}{l}\text { Similar studies at the same time initiated by Adrian } \\
\text { Thrasher et al. in London }\end{array}$ \\
\hline 2003 & $\begin{array}{l}\text { T-cell lymphoproliferative } \\
\text { disease in } 25 \% \text { patients of } \\
\text { X-SCID trials }\end{array}$ & Paris \& London & $\begin{array}{l}\text { Four patients in Paris, one in London (one patient } \\
\text { died, others effectively cured); Leukemia develo- } \\
\text { ped as the consequence of vector integration into } \\
\text { LMO2 oncogene }\end{array}$ \\
\hline 2003 & $\begin{array}{l}\text { Gendicine registered in China } \\
\text { (Adenoviral p53 transfer for } \\
\text { head and neck squamous } \\
\text { carcinoma) }\end{array}$ & Sibiono GeneTech & $\begin{array}{l}\text { Similar approach did not achieve acceptance of } \\
\text { FDA }\end{array}$ \\
\hline $2000-2010$ & $\begin{array}{l}\text { Self-inactivating lentiviral } \\
\text { vectors }\end{array}$ & Many researchers & $\begin{array}{l}\text { Better safety profile for permanent cell modifica- } \\
\text { tion }\end{array}$ \\
\hline $2006 \& 2007$ & $\begin{array}{l}\text { Induced pluripotent stem cells } \\
\text { (iPSC) achieved by genetic } \\
\text { reprogramming of somatic } \\
\text { cells (retroviral overexpression } \\
\text { of four transcription factors: } \\
\text { Oct4, Sox2, KIf4 and c-Myc) }\end{array}$ & $\begin{array}{l}\text { Shinya Yamanaka, Kyoto, } \\
\text { Japan }\end{array}$ & $\begin{array}{l}\text { Nobel prize in } 2012 \text { (together with John Gurdon); } \\
\text { iPSCs became the tool for disease modelling and } \\
\text { therapy }\end{array}$ \\
\hline 2012 & Glybera (alipogene tiparvovec) & UniQure (The Netherlands) & $\begin{array}{l}\text { AAV1 vector with LPL gene injected into the mu- } \\
\text { scles }\end{array}$ \\
\hline 2013 & Gene editing by CRISPR/Cas9 & $\begin{array}{l}\text { proposed by Emannuelle } \\
\text { Charpentier, Jenniffer Doud- } \\
\text { na, and Virginijus Siksnys }\end{array}$ & $\begin{array}{l}2018 \text { - Kavli prize for E. Charpentier, J. Doudna and } \\
\text { V. Siksnys } \\
2020 \text { - Nobel prize for E. Charpentier and J. Do- } \\
\text { udna }\end{array}$ \\
\hline 2015 & $\begin{array}{l}\text { Oncolytic herpes virus talimo- } \\
\text { gene laherparepvec (HSV1- } \\
\text {-GM-CSF) }\end{array}$ & Imlygic, Amgen & Approved for melanoma; intratumoral injection \\
\hline 2016 & $\begin{array}{l}\text { Strimvelis registered } \\
\text { (autologous CD } 34^{+} \text {transduced } \\
\text { with retroviral vector harbo- } \\
\text { ring adenosine deaminase } \\
\text { gene) }\end{array}$ & $\begin{array}{l}\text { Orchard Therapeutics (the } \\
\text { strategy was developed } \\
\text { in San Raffaele Hospital in } \\
\text { Milan) }\end{array}$ & $\begin{array}{l}\text { In contrast to X-SCID, CGD and Wiskott-Aldrich } \\
\text { gene therapy, the insertional mutagenesis has not } \\
\text { occurred in ADA-SCID gene therapy (however, } \\
\text { recent report suggests that it might have occurred } \\
\text { in one patient) }\end{array}$ \\
\hline $\begin{array}{l}2016 \text { (since } \\
2017 \text { in Europe) }\end{array}$ & $\begin{array}{l}\text { Nusinersen (Spinraza) - anti- } \\
\text { sense oligonucleotide targe- } \\
\text { ting intron to restore proper } \\
\text { splicing of SMN2 gene and } \\
\text { synthesis of SMN protein }\end{array}$ & Ionis Pharmaceuticals/Biogen & $\begin{array}{l}\text { Injected intrathecally (oligonucleotides do not } \\
\text { cross the blood-brain barrier); has to be given eve- } \\
\text { ry four months; applicable to all SMA patients }\end{array}$ \\
\hline 2016 & $\begin{array}{l}\text { First patient treated with the } \\
\text { iPSC-derived cells }\end{array}$ & $\begin{array}{l}\text { Masayo Takahashi, Kobe, } \\
\text { Japan }\end{array}$ & $\begin{array}{l}\text { Autologous iPSC differentiated into retinal pigment } \\
\text { epithelial cells to treat adult macular degeneration }\end{array}$ \\
\hline 2017 & $\begin{array}{l}\text { First CAR-T therapy registered } \\
\text { by FDA: } \\
\text { Tisagenlecleucel (Kymriah) (in } \\
2018 \text { by EMA) } \\
\text { Axicabtagene cilolecuel } \\
\text { (Yescarta) - (in } 2018 \text { by EMA) }\end{array}$ & $\begin{array}{l}\text { Novartis/Lite Pharma } \\
\text { Kite Therapeutics }\end{array}$ & $\begin{array}{l}\text { Autologous gene-modified T -cells for intravenous } \\
\text { infusion } \\
\text { For ALL refractory patients younger than } 25 \mathrm{yr} \text { of } \\
\text { age } \\
\text { For certain types of non-Hodgkin lymphoma }\end{array}$ \\
\hline
\end{tabular}




\begin{tabular}{|c|c|c|c|}
\hline 2017 & $\begin{array}{l}\text { Voretigene neparvovec-rzyl } \\
\text { (Luxturna) registered in USA } \\
\text { (in } 2018 \text { in Europe) }\end{array}$ & Spark Therapeutics & $\begin{array}{l}\text { AAV2-vector harboring RPE65 CDNA for RPE65 } \\
\text { Leber's congenital amaurosis; injected subretinally }\end{array}$ \\
\hline 2017 & $\begin{array}{l}\text { Gene therapy for junctional } \\
\text { epidermolysis bullossa - auto- } \\
\text { logous epidermal progenitors } \\
\text { modified with retroviral vector } \\
\text { harboring LAMB3 cDNA }\end{array}$ & $\begin{array}{l}\text { Hirsch et al (M. De Luca, G. } \\
\text { Pellegrini) - Bochum, Germa- } \\
\text { ny - \& Modena, Italy }\end{array}$ & $\begin{array}{l}\text { Five years after the treatment which restored the } \\
\text { healthy epidermis the patient is in very good con- } \\
\text { ditions }\end{array}$ \\
\hline 2019 & $\begin{array}{l}\text { Onasemnogene aberparvovec } \\
\text { (Zolgensma) }\end{array}$ & Novartis & AAV9-SMN1 by intravenous infusion \\
\hline $2019^{\prime}$ & $\begin{array}{l}\text { Conditional approval of Zyn- } \\
\text { teglo } \\
\text { (betibeglogene autotemcel) }\end{array}$ & bluebird bio & $\begin{array}{l}\text { Modification of autologous CD } 34^{+} \text {cells with lentivi- } \\
\text { ral vector harboring the proper } \beta \text {-globin gene }\end{array}$ \\
\hline 2020 & $\begin{array}{l}\text { EMA approves Limbeldy } \\
\text { (OTL-200) }\end{array}$ & $\begin{array}{l}\text { Orchard Therapeutics \& San } \\
\text { Raffaele - Telethon Institute } \\
\text { (Milan) }\end{array}$ & $\begin{array}{l}\text { Autologous CD34+ cells transduced with lentiviral } \\
\text { vector harboring human arylsulfatase-A (ARSA) } \\
\text { gene for metachromatic leukodystrophy }\end{array}$ \\
\hline 2020 & $\begin{array}{l}\text { mRNA and adenoviral vacci- } \\
\text { nes for SARS-COV-2 }\end{array}$ & $\begin{array}{l}\text { mRNA - Pfizer/BioNtech } \\
\text { Moderna } \\
\text { Adenoviral - AstraZeneca; } \\
\text { Janssen, Gamaleya }\end{array}$ & $\begin{array}{l}\text { Hundreds of millions of people vaccinated in De- } \\
\text { cember } 2020 \text { and the first half of } 2021\end{array}$ \\
\hline 2020 & $\begin{array}{l}\text { CRISPR/Cas9 gene-editing } \\
\text { applied to } \\
\text { Leber's congenital amaurosis } \\
\text { patients }\end{array}$ & $\begin{array}{l}\text { Allergan \& Editas Medicine at } \\
\text { Oregon Health and Science } \\
\text { Medicine Center }\end{array}$ & $\begin{array}{l}\text { Subretinal injection of sgRNA/Cas9 (AGN-151587 } \\
\text { (EDIT-101) targeted to a mutation in the CEP290 } \\
\text { gene }\end{array}$ \\
\hline 2021 & $\begin{array}{l}\text { Gene editing \& gene inhi- } \\
\text { bition for the treatment of } \\
\beta \text {-thalassemia and sickle cell } \\
\text { disease }\end{array}$ & $\begin{array}{l}\text { Vertex Pharmaceuticals \& } \\
\text { CRISPR Therapeutics } \\
\text { bluebird bio }\end{array}$ & $\begin{array}{l}\text { CRISPR/Cas9 gene-editing of } B C L 11 A \text { enhancer in } \\
\text { CD34+ cells allows switching on the fetal } \gamma \text {-globin } \\
\text { expression and appears to be effective in two tre- } \\
\text { ated patients } \\
\text { shRNA inhibition of } B C L 11 A \text { gene }\end{array}$ \\
\hline 2021 & $\begin{array}{l}\text { Abecma (idecabtagene vicleu- } \\
\text { cel) registered by the FDA } \\
\text { Breyanzi (lisocabtagene ma- } \\
\text { raleucel) } \\
\text { approved by the FDA }\end{array}$ & $\begin{array}{l}\text { bluebird bio } \\
\text { Bristol Myers Squibb }\end{array}$ & $\begin{array}{l}\text { CAR-T cells therapy for relapsed or refractory mul- } \\
\text { tiple myeloma patients - directed against B-cell } \\
\text { maturation antigen } \\
\text { CAR-T cells therapy for the treatment of adult } \\
\text { patients with refractory or relapsed large B-cell } \\
\text { lymphoma }\end{array}$ \\
\hline
\end{tabular}

Table 3. Advantages and drawbacks of major viral vectors used in gene therapies

\begin{tabular}{|c|c|c|c|c|}
\hline $\begin{array}{l}\text { Type of } \\
\text { vector }\end{array}$ & Features & Advantages & Risk and limitations & $\begin{array}{l}\text { Mitigation approaches for } \\
\text { potential problems/other } \\
\text { approaches }\end{array}$ \\
\hline $\begin{array}{l}\text { Gamma-re- } \\
\text { troviral }\end{array}$ & Capacity $\sim 8 k b$ & $\begin{array}{l}\text { Very well-known biology, } \\
\text { ease of manipulation, }\end{array}$ & $\begin{array}{l}\text { Integration - propensity for } \\
\text { gene regulatory regions }\end{array}$ & $\begin{array}{l}\text { Self-inactivating lentiviral } \\
\text { vectors } \\
\text { Risk of insertional mutage- } \\
\text { nesis may be also linked } \\
\text { with the transgene }\end{array}$ \\
\hline Lentiviral & Capacity 8kb & Infect non-dividing cells & $\begin{array}{l}\text { Difficulties in production } \\
\text { Long term studies not yet } \\
\text { known }\end{array}$ & $\begin{array}{l}\text { Self-inactivating vectors } \\
\text { Restriction of expression } \\
\text { to a given cell type by e.g. } \\
\text { incorporation of miRNA re- } \\
\text { cognition sequence in } 3^{\prime} \text { UTR }\end{array}$ \\
\hline Adenoviral & $\begin{array}{l}\text { Capacity up to } 38 \mathrm{kB} \\
\text { (in case of helper- } \\
\text {-dependent vectors), } \\
\text { usually less, } \sim 8.5 \mathrm{~kb}\end{array}$ & $\begin{array}{l}\text { Easily infect numerous cell } \\
\text { types independently of cell } \\
\text { cycles; } \\
\text { Large scale and high titer } \\
\text { production possible }\end{array}$ & $\begin{array}{l}\text { High risk of systemic inflam- } \\
\text { mation } \\
\text { Preexisting immunity dimini- } \\
\text { shes expression efficacy }\end{array}$ & $\begin{array}{l}\text { Elimination of viral sequen- } \\
\text { ces to limit the inflammatory } \\
\text { response } \\
\text { Change of serotype for the } \\
\text { 2nd injection }\end{array}$ \\
\hline AAV & Capacity up to $4,5 \mathrm{kB}$ & $\begin{array}{l}\text { Non-pathogenic } \\
\text { Permanent transduction of } \\
\text { the post-mitotic cells - neu- } \\
\text { rons, skeletal myoblasts, } \\
\text { cardiomyocytes } \\
\text { Several serotypes demon- } \\
\text { strating tropism for specific } \\
\text { cell types }\end{array}$ & $\begin{array}{l}\text { Size of the transgene vs size of } \\
\text { the gene - this is a drawback } \\
\text { in case of DMD, not in the case } \\
\text { of SMA } \\
\text { Risk of side effect - immune re- } \\
\text { sponse - antibodies to capsid; } \\
\text { activation of cytotoxic T } \\
\text { lymphocytes killing transduced } \\
\text { cells; } \\
\text { Immunity against transgene } \\
\text { protein,e.g. dystrophin (but not } \\
\text { the case for SMN, as its small } \\
\text { amount is produced from the } \\
\text { SMN2 gene ) }\end{array}$ & $\begin{array}{l}\text { Various serotypes to target } \\
\text { specific cells } \\
\text { Delivery of truncated version } \\
\text { of the gene (microdystro- } \\
\text { phins for DMD; shortened } \\
\text { factor VIII for treatment of } \\
\text { hemophilia A) }\end{array}$ \\
\hline
\end{tabular}


and adeno-associated viral (AAV) vectors comprising the vast majority of application in clinical trials of gene therapies (see The Gene Therapy Clinical Trials Worldwide: https://a873679.fmphost.com/fmi/webd/ GTCT) (Fig. 1, Table 3). The strategy of their application for treatment of patients relies on the removal of unnecessary genes, particularly those which are responsible for pathogenicity of the virus, making the vectors safe but still retaining the capacity to deliver nucleic acid into the cells (for reviews see: (Giacca \& Zacchigna, 2012; Dunbar et al., 2018; High \& Roncarolo 2019; Li \& Samulski, 2020). First of all, the genes responsible for viral replication are deleted in order to prevent replication of the vector after injection into the patient. Second, additional genes are removed to restrict the immune reaction to the vectors and to increase the capacity for the transgene (therapeutic gene). In the case of integrating retroviral/ lentiviral vectors, the modifications also concern the sequences which may limit the effect of integration in the unwanted sites. The latter and other modifications arise as the result of side effects observed in early clinical trials (see below). Hence, the potential and safety of future genetic therapies will hopefully increase thanks to the combination of basic research and observation of the outcomes of clinical trials.

The consequence of such manipulations is dependent on the type of the vector. First, various vectors have different packaging capacities, hence their application for delivery of a given sequence may be dictated by the size of the viral genome (Table 3). Second, depending on the viral properties, the vector can allow only for the transient modification of the cells, as without integration the vector is lost by the dividing cells. Nevertheless, even non-integrating vectors can provide long-term expression in post-mitotic cells, such as muscle fibers or neurons, if they are not eliminated by the immune response $(\mathrm{Li} \&$ Samulski, 2020). Third, the efficacy of transduction may depend on the cell cycle state of the cell being transduced, as some vectors transduce only the dividing cells due to their inability to pass the nuclear membrane. This is the case of the gamma-retroviral vectors which unlike the lentiviral vectors cannot transduce cells when they do not proliferate (High \& Roncarolo, 2019).
The persistence of the introduced gene expression is dependent not only on the integration, but also on the immunogenicity of the vector used. As a large number of viral particles is injected into the patient and in the same way the amount of viral proteins particularly present in the capsid are exposed to the immune system of the patient, the pre-existing immunity may lead to rapid elimination of the vector and vanishing of the efficacy of therapy. This is of concern for adenoviral and to a lesser extent for AAV vectors, as the pre-existing neutralizing antibody can lead to vector elimination, but can also cause a strong inflammatory response, particularly in the case of adenoviral vectors. In an extreme situation, this can create the risk of death, as it, unfortunately, happened in the well-known ornithine transcarbamylase (OTC) trial in 1999, when 18-years old Jesse Gelsinger had died a few days after intravenous injection of the OTC-harboring adenovirus (Dunbar et al., 2018). The same concerns the potential risk of the lower effectiveness of the adenoviral vector-based vaccines, although the ongoing "life" trials with the anti-SARS-CoV-2 vaccines indicate that the fears may not be fulfilled.

The critical problem associated with the vectors' safety is their capacity to integrate into the cell genome. While the permanent cell modification is necessary for the life-long effect of gene therapy in inherited diseases, the usually random vector integration exposes patients to the risk of side effects that have to be balanced with the benefits of the therapy. This is the best exemplified in the case of gene therapy of immunodeficiency syndromes, in which the hematopoietic stem and progenitor cells (HSPC) are transduced with retroviral vectors. In original studies with the treatment of the X-linked severe combined immunodeficiency syndrome (X-SCID) (see below), modified gamma-retroviral vectors have been used. These trials have demonstrated high efficacy resulting in the restoration of the immune system of boys suffering from the lack of the proper $\gamma_{c}$ chain gene, the mutation responsible for this X-SCID form of immunodeficiency. However, within a few years after therapy, $25 \%$ of boys experienced an uncontrolled $\mathrm{T}$ cell proliferative response due to vector integration in the promoter of the LMO2 gene, leading to an acute Tcell lymphoproliferative disorder (Staal et al., 2019; Kohn

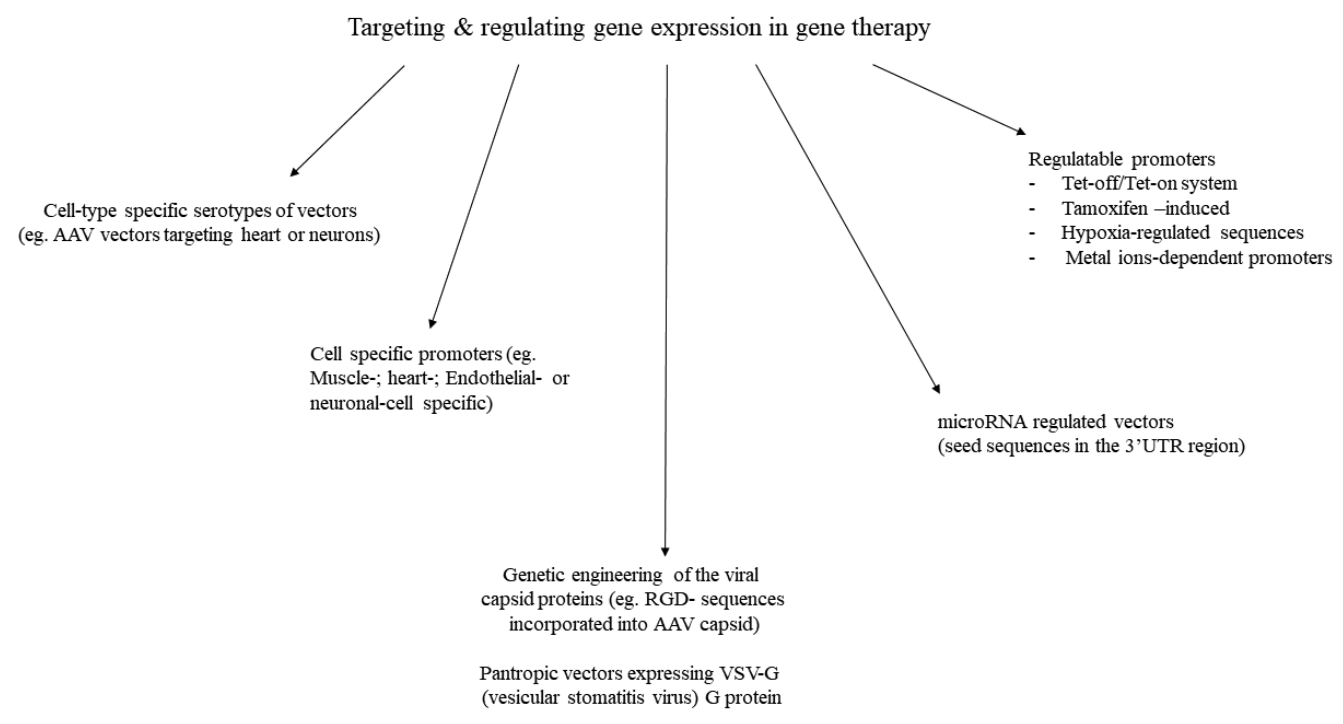

Figure 2. Regulation of gene expression used in experimental gene therapies 
\& Kohn, 2021). As a consequence, clinical trials with the gamma-retroviral vectors in X-SCID were stopped. Similar problems have been observed in a few other immunodeficiency diseases, such as the Wiskott-Aldrich (Braun et al., 2014) and the chronic granulomatous disease - CGD (Braun et al., 2014; Stein et al., 2010), with the latter caused by insertion in the MDS1/EVI1 gene. Researchers determined to solve this problem switched to the HIV-based lentiviral vectors, which thanks to the possibility of modification resulting in self-inactivation appear to be a safer approach (Staal et al., 2019). Better lentiviral vector safety is also linked to their integration into the transcriptionally active regions, in contrast to gammaretroviruses, demonstrating propensity to promoters (Wu et al., 2003; Montini et al., 2009; Trono, 2012).

Efficacy of transduction of the cells is strictly dependent on the presence of receptors for a given virus on the cell surface. Therefore, when targeting different cells is necessary, different serotypes of vectors can be used. For adenoviral vectors, changing of serotypes in case of repeated injection may also limit the vector elimination and increase the effectiveness. Different AAV serotypes characterized by dependence on various receptors allow an efficient transduction of difficult to reach tissues, like the central nervous system or the heart after intravenous injection ( $\mathrm{Li} \&$ Samulski, 2020). Efficacy of therapeutic gene expression also depends on the endogenous machinery of the cells allowing efficient expression of viral genes after transduction. This can happen in the case of AAV vectors, which are single-stranded DNA, and their expression in the cells is dependent on previous formation of double-stranded DNA. To overcome this problem, self-complementary AAV vectors are used (Li \& Samulski, 2020).

A variety of viral serotypes and viruses allow modification of different cell types. Nevertheless, due to the obvious reasons relating to the ease of their manipulation, based on extensive studies, some vectors predominate both in research and clinical applications. These are retroviral vectors, including the lentiviral ones based on $\mathrm{HIV}$, adenoviral vectors, and AAV vectors (Fig. 1; Table 3) https://a873679.fmphost.com/fmi/webd/GTCT. Besides modifications necessary for the safety of the vectors, other manipulations allow improving the targeting of vectors to different cells by experimenting with the proteins on the surface of the viral capsid. Introduction of proper regulatory sequences can increase not only the level of expression of the therapeutic gene, but by applying cell-specific promoters it can additionally target and limit gene expression to a given cell type (Fig. 2). Regulation of gene expression is also possible by applying regulatory sequences activated by specific molecules, like antibiotics (doxycycline), hormones (tamoxifen), or incorporating sequences responding to environmental stimuli, like the changes in the oxygen level (for review see: Jazwa et al., 2013) (Fig. 2). Targeting gene expression to given cells and preventing expression in unwanted cell types is possible by including regulatory sequences in the 3'region of the transgene (therapeutic gene), such as the ones recognized by specific microRNAs, mainly those which demonstrate a cell-limited expression (Naldini, 2019; Kraszewska et al., 2020). However, as our recent study indicates (Kraszewska et al., 2020), the cellular specificity of miRNAs has to be carefully checked as it can be not as well restricted as the original studies claimed. On the other hand, overexpression of cell- and organ-specific microRNAs is promising in experimental gene therapy studies, e.g. in heart diseseases (for review see: (Cannatà et al., 2020; Braga et al., 2021)).
All of the above-discussed types of vectors have been applied in registered clinical gene therapies, which will be briefly described below. However, it is not possible here to discuss numerous aspects of experimental gene therapy in different diseases, and the readers are therefore referred to other, excellent reviews (Dunbar et al., 2018; High \& Roncarolo, 2019; De Luca et al., 2019; Korpela et al., 2021).

\section{CLINICAL APPLICATIONS OF GENE THERAPY}

Coincidentally, close to the time when Wacław and Elisabeth Szybalski had been performing their experiments, the rare genetic disease, caused by a mutation in the $\mathrm{X}$ chromosome-located HPRT gene, has been recognized by Michael Lesch and William Nyhan. This severe neurological disease, manifested by autoaggressive, self-mutilating behavior of affected patients, and development of uric acid stones in the kidneys and joints is since that time named the Lesch-Nyhan syndrome (Kelley \& Andersson, 2014). Unfortunately, despite the enormous development of gene therapy strategies, the Lesch-Nyhan syndrome is not treatable, due to the complexity of this genetic disorder, which would most probably require gene therapy early in life, even in utero, and difficult if not impossible manipulation of the nervous system cells.

Nevertheless, it took almost 30 years till the time when the first controlled clinical trials of gene therapy have been performed. Historically, the first vectors applied for human gene therapy were the retroviral ones. In 1989 the first controlled transduction of lymphocytes of a patient suffering from end-stage melanoma was performed (Rosenberg et al., 1990). The approach was aimed not to treat the disease, but to demonstrate the feasibility of the retroviral vectors to stably modify the cells. The marker gene, encoding bacterial neomycin transferase, was incorporated into the retroviral backbone and the tumor-infiltrating lymphocytes of the patient collected two months after delivery demonstrated its expression (Rosenberg et al., 1990; Culver et al., 1991).

\section{Gene therapy of severe combined immunodeficiencies}

In the next years, retroviral vectors were used to modify the cells of severely immunodeficient patients suffering from adenosine deaminase-type of the disease (ADASCID). The first controlled clinical trial of gene therapy for this type of immunodeficiency was performed in two girls at NIH in Bethesda by Blaese and co-workers in 1991 (Culver et al., 1991). The outcome was successful, as the modified cells were found in their blood 4 years after the injection (Blaese et al., 1995) and some, although very rare, modified lymphocytes were detected after 12 years (Muul et al., 2003). Nevertheless, from the scientific point of view, the experiment was not stringent enough. Due to various reasons, the patients have not been treated only with the genetically modified cells, but have been also injected with the then-registered ADAPEG. As this ready-to-use enzyme appeared to be the effective treatment for those ADA-SCID patients who do not qualify for the allogeneic bone marrow transplantation, the outcome of the first gene therapy cannot be ascribed only to the effect of genetically modified cells. However, ADA-PEG has to be given through-out the whole life, the cost of the treatment is high (Table 4), and there is a risk of development of intolerance.

In 2000, another, fully successful gene therapy has been reported by French researchers. The team of 
Table 4. Costs of some registered and conditionally approved genetic therapies in Europe and the USA

\begin{tabular}{|c|c|c|c|c|c|}
\hline $\begin{array}{l}\text { Drug } \\
\text { (producer/supplier) }\end{array}$ & $\begin{array}{l}\text { Vector /type of } \\
\text { nucleic acid }\end{array}$ & Indication & $\begin{array}{l}\text { Number of patients } \\
\text { to be treated }\end{array}$ & $\begin{array}{l}\text { Cost per dose/ } \\
\text { patient }\end{array}$ & $\begin{array}{l}\text { Management therapies/ } \\
\text { other therapies available }\end{array}$ \\
\hline $\begin{array}{l}\text { Glybera } \\
\text { (UniQure) }\end{array}$ & $\begin{array}{l}\text { AAV1 with } L P L \\
\text { gene }\end{array}$ & $\begin{array}{l}\text { Lipoprotein lipase } \\
\text { deficiency (LPLD) }\end{array}$ & $\begin{array}{l}\text { prevalence of LPLD - } \\
1-2 \text { per million; } \\
\text { till } 2018 \text { only } 31 \\
\text { patients treated (but } \\
\text { mostly in clinical } \\
\text { trials, as the price of } \\
\text { the drug was restric- } \\
\text { tive - finally the drug } \\
\text { has been withdrawn } \\
\text { from the market) }\end{array}$ & 1.2 million $€$ & $\begin{array}{l}\text { Restricting fat in diet; } \\
\text { lipid-lowering therapy } \\
\text { (not sufficiently effec- } \\
\text { tive) }\end{array}$ \\
\hline $\begin{array}{l}\text { Strimvelis } \\
\text { (GlaxoSmithkline/Or- } \\
\text { chard Therapeurtics ) }\end{array}$ & $\begin{array}{l}\text { CD34+ modified } \\
\text { with } A D A \text { gene } \\
\text { (lentiviral) }\end{array}$ & ADA -SCID & $\begin{array}{l}\text { Approx. } 15 \text { patients/ } \\
\text { year in Europe; } 12 \text { in } \\
\text { the USA }\end{array}$ & $594,000 €$ & $\begin{array}{l}\text { Enzyme replacement } \\
\text { (ADA-PEG)- } 3.6 \text { mil- } \\
\text { lion } € \text { for one patient } \\
\text { over } 4 \text { years }\end{array}$ \\
\hline $\begin{array}{l}\text { Luxturna } \\
\text { (Spark Therapeutics/ } \\
\text { Novartis) }\end{array}$ & $\begin{array}{l}\text { AAV2 with RPE65 } \\
\text { gene }\end{array}$ & $\begin{array}{l}\text { RPE65 mutation } \\
\text { (Leber's congeni- } \\
\text { tal amaurosis) }\end{array}$ & $\begin{array}{l}1,000-2,000 \text { in the } \\
\text { USA } \\
10-20 \text { children born } \\
\text { /year }\end{array}$ & $\begin{array}{l}360,000 € / \text { eye } \\
720,000 € \text { total }\end{array}$ & $\begin{array}{l}\text { No other efficient thera- } \\
\text { py available }\end{array}$ \\
\hline $\begin{array}{l}\text { Zolgensma } \\
\text { (Novartis) }\end{array}$ & $\begin{array}{l}\text { AAV9 with SMN1 } \\
\text { gene }\end{array}$ & $\begin{array}{l}\text { Spinal muscular } \\
\text { atrophy }\end{array}$ & $\begin{array}{l}\text { About } 800 \text { patients in } \\
\text { Poland; } \\
\text { 30-50/year }\end{array}$ & $\begin{array}{l}1,8 \text { million } € \\
(\$ 2,100000 \text { in US; } \\
\text { or } \$ 425,000 / \text { year } \\
\text { over } 5 \text { years })\end{array}$ & Spinraza (see below) \\
\hline $\begin{array}{l}\text { Spinraza (nusinersen) } \\
\text { lonis Pharmaceuticals/ } \\
\text { Biogen }\end{array}$ & $\begin{array}{l}\text { Antisense oligo- } \\
\text { nucleotide }\end{array}$ & $\begin{array}{l}\text { Spinal muscular } \\
\text { atrophy }\end{array}$ & As above & $\begin{array}{l}635,000 € / 1^{\text {st }} \text { year } \\
318,000 € \text { there- } \\
\text { after }\end{array}$ & Zolgensma (see above) \\
\hline $\begin{array}{l}\text { Kymriah tisagenlec- } \\
\text { leucel } \\
\text { (Novartis) }\end{array}$ & $\begin{array}{l}\text { CAR-T for CD19 } \\
\text { antigen common } \\
\text { on B cells }\end{array}$ & $\begin{array}{l}\text { B-cell acute lym- } \\
\text { phoblastic leu- } \\
\text { kemia (ALL) - in } \\
\text { patients up to } 25 \\
\text { years old }\end{array}$ & $\begin{array}{l}2,500 \text { case/year in the } \\
\text { USA; roughly } 600 \text { do } \\
\text { not respond to stan- } \\
\text { dard treatment }\end{array}$ & $\begin{array}{l}400,000 € \\
(\$ 475,000)\end{array}$ & $\begin{array}{l}\text { The cost of the drug } \\
\text { does not include the } \\
\text { cost of management } \\
\text { of the cytokine release } \\
\text { syndrome \& other com- } \\
\text { plications }\end{array}$ \\
\hline $\begin{array}{l}\text { Yescarta (axicabtagene } \\
\text { ciloleucel) } \\
\text { (Kite Pharma/Gilead) }\end{array}$ & $\begin{array}{l}\text { CAR-T for CD19 } \\
\text { antigen }\end{array}$ & $\begin{array}{l}\text { Diffuse Large B- } \\
\text {-cell lymphoma }\end{array}$ & $\begin{array}{l}24,000 \text { cases/year in } \\
\text { USA }\end{array}$ & $\begin{array}{l}316,000 € \\
(\$ 373,000)\end{array}$ & As above \\
\hline $\begin{array}{l}\text { Tecartus (brexucabta- } \\
\text { gene autoleucel) } \\
\text { (Kite Pharma/Gilead) }\end{array}$ & $\begin{array}{l}\text { CAR-T for CD19 } \\
\text { antigen }\end{array}$ & $\begin{array}{l}\text { Mantle cell lym- } \\
\text { phoma (a subset } \\
\text { of non-Hodgking } \\
\text { lymphoma) }\end{array}$ & $\begin{array}{l}15,000 \text { patients in } \\
\text { USA }\end{array}$ & $\begin{array}{l}316,000 € \\
(\$ 373,000)\end{array}$ & $\begin{array}{l}\text { Similar as Yescarta, } \\
\text { targets the same CD19 } \\
\text { antigen, different manu- } \\
\text { facturing process }\end{array}$ \\
\hline $\begin{array}{l}\text { Zynteglo } \\
\text { (bluebird bio) }\end{array}$ & $\begin{array}{l}\text { Autologous } \\
\text { CD34+ modified } \\
\text { with lentiviral } \\
\text { vector with } \\
\text { proper } \beta \text {-globin } \\
\text { gene }\end{array}$ & $\beta$--thalassemia & $\begin{array}{l}\text { Global incidence - } \\
1: 100,000\end{array}$ & $\begin{array}{l}1,525,000 € \\
(\$ 1,800000)\end{array}$ & $\begin{array}{l}\text { Blood transfusion - side } \\
\text { effects affect patients' } \\
\text { life quality and expec- } \\
\text { tancy; } \\
\text { Allogeneic bone marrow } \\
\text { transplantation available } \\
\text { only for a minority of } \\
\text { patients }\end{array}$ \\
\hline $\begin{array}{l}\text { (T-VEC) Talimogene la- } \\
\text { herparepvec (Imlygic) }\end{array}$ & $\begin{array}{l}\text { Oncolytic herpes } \\
\text { virus }\end{array}$ & Melanoma & & $\begin{array}{l}55,000 € \\
(\$ 65,000)\end{array}$ & $\begin{array}{l}\text { To be applied after all } \\
\text { other anti-cancer thera- } \\
\text { pies failed }\end{array}$ \\
\hline $\begin{array}{l}\text { Exondys } 51 \text { (eteplirsen) } \\
\text { (Sarepta) } \\
\text { Conditional approval } \\
\text { by FDA, not approved } \\
\text { by EMA; } \\
\text { Vyondys } 53 \text { (Golodir- } \\
\text { sen) - Sarepta and } \\
\text { Viltepso (vitolarsen) - } \\
\text { NS Pharma }\end{array}$ & $\begin{array}{l}\text { Exon skipping } \\
\text { oligonucleoti- } \\
\text { de- } \\
\text { Eteplirsen skips } \\
\text { exon } 51 \text {, golodir- } \\
\text { sen and vitolar- } \\
\text { sen exon } 53\end{array}$ & $\begin{array}{l}\text { Duchenne mu- } \\
\text { scular dystrophy }\end{array}$ & $\begin{array}{l}\text { DMD incidence is } \\
\text { about 1:5,000 boys; } \\
\text { exon skipping is } \\
\text { amenable to patients } \\
\text { with given mutation } \\
\text { (about } 14 \% \text { in case of } \\
\text { eteplirsen; about } 8 \% \\
\text { for golodirsen and } \\
\text { vitolarsen }\end{array}$ & $\begin{array}{l}255,000 € \\
(\$ 300,000 / \text { year })\end{array}$ & $\begin{array}{l}\text { Deflazacort (steroid) - } \$ \\
89,000 / \text { year } \\
\text { (but prednisolone is } \\
\text { much cheaper) - howe- } \\
\text { ver, steroids do not cure } \\
\text { DMD }\end{array}$ \\
\hline $\begin{array}{l}\text { Onpattro (patisiran) } \\
\text { (Alnylam) }\end{array}$ & $\begin{array}{l}\text { siRNA targeting } \\
\text { tranthyretin } \\
\text { mRNA }\end{array}$ & $\begin{array}{l}\text { Hereditary trans- } \\
\text { thyretin-media- } \\
\text { ted amyloidosis } \\
\text { (hATTR) }\end{array}$ & $\begin{array}{l}\text { About } 50,000 \text { patients } \\
\text { worldwide }\end{array}$ & $\begin{array}{l}380,000 € \\
(\$ 450,000 / \text { year } \\
(\sim \$ 10,000 \text { per vial })\end{array}$ & $\begin{array}{l}\text { No effective treatment; } \\
\text { potentially liver trans- } \\
\text { plant in the early phase } \\
\text { of the disease }\end{array}$ \\
\hline
\end{tabular}

Marina Cavazzana and Alain Fischer from the Necker Hospital in Paris have treated boys suffering from the X-SCID, caused by a mutation in the $\gamma c$ chain of the interleukin receptor (IL2RG) (Cavazzana-Calvo et al., 2000). The disease is fatal if not treated by bone marrow transplantation and the patients, named "bubble boys", are at a risk of death due to even mild infections. Moreover, unlike the ADA-deficiency, this disease cannot be treated by an enzyme replacement therapy, as the $\gamma_{c}$ protein is membrane-bound. Allogeneic bone marrow transplantation is the therapy of choice for the $\mathrm{X}-\mathrm{SCID}$ patients, however, its success is limited, associ- 
ated with a risk of side effects, and hindered by lack of a sufficient number of donors. To overcome these limitations, the French team modified the patients' bone marrow-derived HSPC with the gamma-retroviral vectors harboring the $\gamma_{c}$ chain encoding sequence. Similar success was soon thereafter achieved by Adrian Trasher and co-workers working at the Great Ormond Street Hospital in London (Gaspar et al., 2004). The reinfused modified cells repopulated the bone marrow and the outcome of therapy was breathtaking, as the restoration of the immune system has been observed in 18 out of 20 treated patients (Kohn \& Kohn, 2021). Unfortunately, at 2-14 years after the therapy, in 6 out of 20 treated patients, an uncontrolled proliferation of T-cells was observed which resembled the ALL ((Staal et al., 2019; Kohn \& Kohn, 2021). These patients have been effectively cured of leukemia but one, who unfortunately have died (Hacein-Bey-Abina et al., 2010). A detailed analysis revealed that the problem was caused by the vector-induced insertional mutagenesis. Although its integration is random, it appeared that incorporation into the promoter of the LMO2 gene, regulating proliferation of hematopoietic cells, caused the uncontrolled cell growth (Hacein-Bey-Abina et al., 2003). The studies have been stopped and the efforts have been concentrated on the development of safer vectors. It has been later demonstrated that the HIV-based lentiviral vectors can be manipulated in a way allowing their self-inactivation, limiting the risk of uncontrolled activation of the oncogenes (Staal et al., 2019; Kohn \& Kohn, 2021). Accordingly, recent clinical trials performed in the USA demonstrated some effectiveness of the lentiviral vector-based gene therapy in X-SCID (De Ravin et al., 2016; Mamcarz et al., 2019), X-linked chronic granulomatous disease (Kohn et al., 2020), and recently they have been shown to be highly efficient in a clinical trial in 50 ADA-SCID patients (Kohn et al., 2021).

Interestingly, although exactly the same gammaretroviral vector was used, gene therapy of ADA-SCID immunodeficiency appeared to be very successful, with a $100 \%$ survival rate of patients over 2 to 13 years after therapy, and devoid of serious side effects (Cicalese et al., 2016). These results finally led to registration of Strimvelis (Hoggatt, 2016). Accordingly, Strimvelis is an approach in which the autologous CD $34^{+}$HSPC of patients suffering from ADA-SCID are transduced in vitro with a gammaretroviral vector harboring the proper ADA gene sequence. Strimvelis was the 2nd gene therapy officially registered in Europe, preceded by Glybera approved in 2012 (YläHerttuala, 2012), which, however, has been withdrawn due to the very high price, lack of interest, and concerns of the cost-effectiveness benefits.

The several years-long clinical trials and observations performed at the San Raffaelle Hospital in Milan have proven that Strimvelis is effective and safe for more than 40 children for whom the allogeneic haploidentical bone marrow transplantation was not possible or who did not qualify for the enzyme replacement therapy with ADA-PEG due to unwanted side effects (Ferrua \& Aiuti, 2017). Currently, the longest survival reported after ADA-SCID gene therapy is 18 years, although five of the initial 22 subjects treated required additional allogeneic bone marrow transplantation or ADA-PEG therapy due to failure of gene therapy (Tucci et al., 2021). After registration Strimvelis has been applied in Milan in 12 subjects so far (Tucci et al., 2021). Similar positive results have been noted in patients treated in the frame of clinical trials in the UK and USA, with no evidence of serious insertional mutagenesis (Shaw et al., 2017).

What is crucial for the success of the HSPC-based autologous gene therapy is elimination, at least partial, of the non-modified autologous hematopoietic stem/ progenitor cells (HSPC), to create room for the transplanted cells. This is achieved by myeloablation, performed by an alkylating agent (mostly busulfan) treatment (for review see: De Luca et al., 2019; Ferrari et al., 2021). Emptying the niche facilitates the modified cells' engraftment and improves restoration of the immune system. Withholding the enzyme replacement therapy, offered as the first choice for the ADA patients, is also a prerequisite for expansion of the gene-corrected cells (for references see: High \& Roncarolo, 2019). The myeloablative approach is, however, linked to the risk of toxicity, bone marrow failure, and secondary tumor development (Ferrari et al., 2021).

Recently, the results of clinical trials on $\mathrm{CD}_{3} 4^{+}$cells modified with lentiviral vectors harboring the ADA gene have been published (Kohn et al., 2021). The studies performed in the USA and UK demonstrated a very high efficacy of the therapy, reaching almost 100\% correction of $\mathrm{CD}_{3} 4^{+}$cells and restoration of the immune system. This approach may offer an additional level of efficacy and safety. Although Strimvelis is registered and its safety is demonstrated, one has to be aware of the still certain risks of side effects. Recently, the T-lymphoproliferative disease has been noted in a Strimvelis-treated patient three years after the therapy (Kohn et al., 2021), and studies are underway to elucidate if there is a link with gene therapy.

\section{Gene therapy of leukodystrophies}

Hematopoietic stem cells (HSCs) home to bone marrow niches where they can self-renew, differentiate and continuously generate blood cells and the immune cells. Gene therapy based on HSPC modification is applied in treatment of blood disorders, such as severe immunodeficiencies and anemias. It is also presumed that HSPC which differentiate into the macrophages, may contribute to the treatment of some neurological diseases, in which macrophages derived from modified hematopoietic progenitors could pass the blood-brain barrier and secrete the missing factors. Based on this rationale, bone marrow transplantation is considered to ameliorate the nervous system damage caused by the lack of proper metabolic enzymes. Allogeneic bone marrow transplantation has been thus applied for the treatment of leukodystrophies. However, this approach has limited efficacy and is prone to side effects. Therefore, as a potentially better alternative, genetic modification of autologous HSPC is tested for the treatment of adrenoleukodystrophy (ALD) or metachromatic leukodystrophy (Poletti \& Biffi, 2019). In these trials, the lentiviral vectors have been used to modify patients'

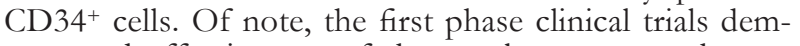
onstrated effectiveness of the autologous gene therapy for X-linked ALD (Eichler et al., 2017) and early-onset metachromatic leukodystrophy (Biffi et al., 2013; Sessa et al., 2016). It appears, however, that the timing of the therapy is crucial and to achieve the effect it has to be initiated before the symptom develops. Nevertheless, there is a hope for further development and as an indication of that the European Medicines Agency (EMA) approved OTL-200 (Limbeldy ${ }^{\mathrm{TM}}$ ) in 2020, which is comprised of autologous $\mathrm{CD}^{+} 4^{+}$cells transduced with lentiviral vector harboring human arylsulfatase- 
A (ARSA) gene. This product, developed by Orchard Therapeutics in collaboration with the San RaffaeleTelethon Institute in Milan, is indicated for treatment of patients with metachromatic leukodystrophy. Its registration was based on at least seven year long clinical benefits observed in 30 out of 33 treated patients (Tucci et al., 2021; https://www.ema.europa.eu/en/news/ new-gene-therapy-treat-rare-genetic-disorder-metachromatic-leukodystrophy).

\section{Gene therapy of $\beta$-thalassemia and sickle cell disease}

Zynteglo (betibeglogene autotemcel), produced by bluebird bio, is the recently registered gene therapy for treatment of $\beta$-thalassemia. In this approach, the retroviral vector harboring a proper human $\beta$-globin gene (bA-T87Q globin) is transduced to autologous CD34 ${ }^{+}$ cells of the patients. The results of clinical trials have demonstrated a long, up to 56 months transfusion independence of the treated patients' (Thompson et al., 2018), which made the justification for the conditional approval of Zynteglo by EMA. The therapy has been registered for patients who have to be 12 years of age or older, with transfusion-dependent $\beta$-thalassemia (High \& Roncarolo, 2019).

The bluebird bio company is also elaborating on the development of a similar strategy for the sickle cell disease (SCD). Nevertheless, recently this study (ClinicalTrials.gov: NCT02140554) has been suspended when one of the participants developed an acute myeloid leukemia/myelodysplastic syndrome (Jones \& DeBaun, 2021).

The very interesting strategy for therapy of $\beta$-thalassemia and SCD is currently tested with the application of gene editing approaches. Besides expression of a proper $\beta$-globin gene, which is mutated in these diseases, researchers are trying to elaborate one restoration of the fetal hemoglobin expression. As the gene for the fetal $\gamma$-chain is not mutated in the patients, and it has been active when in utero, its therapeutic expression can be potentially safer, as there will be no immune response to the fetal globin. Recently, the results of clinical trials of a few patients have been published, and are discussed below (see: Gene editing).

\section{FIRST REGISTERED GENE THERAPIES}

Although Strimvelis is the first effectively applied registered gene therapy, it was not the first one that was officially approved. In 2003, the Chinese medical agency has registered Gendicine, an adenoviral vector harboring correct p53 for use together with radiotherapy in patients with the head and neck cancer (Guo \& Song, 2018). However, the effectiveness of Gendicine is disputable and it has to be noted that exactly the same strategy (Senzer \& Nemunaitis, 2009), despite years of clinical trials, did not receive authorization from FDA in the USA.

In 2012, EMA has registered Glybera, an AAV1 vector harboring the lipoprotein lipase (LPL) gene, for application in familial LPL-deficient patients (Ylä-Herttuala, 2012), a very rare disease characterized by acute pancreatitis. Its registration was associated with discussion on the real effectiveness of Glybera. These concerns and the high cost, exceeding one million Euro, influenced application of the therapy, which after registration was in fact given to only one patient and finally this medicine was withdrawn from the market.

\section{AAV-BASED GENE THERAPIES}

AAV vectors are small DNA vectors, built by singlestranded DNA containing 4.8 kilobases nucleotides (for review and references see: (Li \& Samulski, 2020)). The original AAV virus contains only two genes, rep encoding proteins responsible for viral replication, and cap encoding the capsid proteins and an assembly-activating protein. The AAV vectors have been considered as particularly promising tools for gene therapy due to wild type AAV's capacity to integrate into a specific site on the 19th chromosome (19q13.4 qtr; AAVS1). Moreover, due to the fact that AAV were not linked to any known disease and hence were recognized as nonharmful, and because of their specific integration site, they were considered as particularly promising for therapy of inherited diseases. However, during preparation of the vectors, when the rep and cap genes are removed, the specific integration capacity is lost. Then it appeared that integration is dependent not only on the presence of the ITR sequences at the 5' and 3' end of AAV, but also requires the rep protein. However, due to the small capacity of AAVs, removal of the rep gene is necessary, moreover, the rep proteins are involved in viral replication, induce immune response and when expressed at the high level are toxic for the cells. Nevertheless, the ease of manipulation of the AAV vectors, several existing serotypes, and the overall safety, resulted in their widespread application despite the loss of specific integration. Moreover, when AAV vectors target the non-dividing cells, such as neurons or muscles, they can persist for a long time even without integration (although some integration, but not a specific ones, can be still achieved due to the ITR sequences).

The safety of AAVs was supported by the lack of known diseases caused by these viruses. Nevertheless, in the course of gene therapies performed, it was revealed that preexisting immunity (AAV neutralizing antibodies), as well as induction of the immune response when high doses of AAV vectors are delivered, can result in an aggravated inflammatory response. This problem has been observed in some gene therapy trials of hemophilia, in which it was diminished with corticosteroids. Unfortunately, recently in trials of myotubular myopathy two unexpected deaths had occurred. However, this might be linked to a higher dose applied in these patients, as the patients receiving a lower amount of AAV did well and demonstrated improvement (Sun \& Roy, 2021).

Nevertheless, the AAV vectors are among the most successful in regard to clinical gene therapies. So far, three AAV-based gene medicines have been registered, although as mentioned, AAV1 Glybera has been withdrawn. However, AAV9 Zolgensma (for treatment of spinal muscular atrophy) and AAV2 Luxturna (for treatment of the Leber's congenital amaurosis) appear to be effective. Overall, the AAV vectors are used so far in more than 200 human studies (Sun \& Roy, 2021).

\section{Luxturna}

Inherited retinal diseases cause visual disability with a high frequency of 1:1000. Nevertheless, these diseases are heterogeneous and comprise a large group of more than 300 monogenic diseases (for references see: Cideciyan et al., 2021). Hence, various genetic strategies might be necessary to treat them.

Mutation in the RPE65 gene leads to the damage of retinal pigment cells and finally results in the blindness of the affected patients, creating one of the groups of 
Leber congenital amaurosis, the most severe and childhood-onset blindness (Chen et al., 2021). RPE65 encodes an enzyme converting all-trans-retinyl ester to 11-cis retinol, a necessary component of the visual cycle in the retinal pigment epithelium. An AAV vector harboring the RPE65 gene gained approval by FDA after a phase III clinical trial and a 4-year follow up which demonstrated effectiveness of the therapy. It is sold under the name Luxturna (voretigene neparvovec-rzyl) by Spark Therapeutics in the USA and by Novartis in other countries (Maguire et al., 2021) (Table 1 and 4).

The efficacy of AAV in the treatment of blindness is the consequence of several factors. First, the eye is immune-privileged, hence the immune response against the transgene and the vector is limited. Second, although treatment of blindness requires permanent expression of a therapeutic gene and despite the fact that the AAV vectors do not specifically integrate, this does not hinder transfection efficacy as the transduced epithelial pigment cells do not divide.

Localized expression of RPE65 can treat this form of inherited blindness, however, one has to remember that not all of these diseases qualify for AAV delivery due to the size of the affected gene. Accordingly, in another form of Leber's congenital amaurosis, caused by a mutation in the CEP290 gene, gene-editing strategy started to be tested recently (Ledford, 2020) (see below).

One also has to note the stem cell-based therapy approaches to treat a genetic blindness caused by improper retina functioning. The pigment epithelial cells obtained by differentiation of embryonic stem cells (ESC) are tested in the Stargardt's disease and the results of the early trials are promising (Schwartz et al., 2015). The ESC-derived pigment epithelial cells are also applied for the treatment of adult macular degeneration (da Cruz et al., 2018). In Japan, early-stage clinical trials with induced pluripotent stem cells (iPSC)-derived epithelium have been initiated in such patients. In this approach, performed so far in one patient, the pigment epithelial cells are obtained by differentiation of autologous iPSC (Mandai et al., 2017).

Although stem cell therapies are not "classical" gene therapy, one has to remember that the action of cells obtained by differentiation of stem cells is to restore proper expression of the missing gene(s). In such a case, stem cells, such as HSPC, can be considered as the vehicle of the proper gene. These can be also differentiated cells when direct delivery of stem cells is not possible due to the risk associated with pluripotent stem cells (ESC or iPSC), which when undifferentiated, can form teratomas in the patients.

\section{GENETIC THERAPIES FOR SPINAL MUSCULAR ATROPHY}

After cystic fibrosis, spinal muscular atrophy (SMA) is the 2nd most common autosomal recessive disorder in humans, and it is also the most common genetic cause of death in childhood (Wirth, 2021; Wirth et al., 2020), with the incidence from 1:6000 to 1:10 000. SMA is caused by a mutation in the SMN1 (survival motor neuron) gene. SMN1 is a ubiquitous protein, involved in transcriptional regulation and intracellular trafficking, and its lack particularly results in a selective motor neuron death. Accordingly, the most common feature of SMA is the loss of spinal motor neurons, and due to the impairment in the functions of neuromuscular junctions (NMJ), the disease is characterized by a progressive weakness and atrophy of the proximal voluntary muscles (Wirth, 2021; Wirth et al., 2020).

As described in a very comprehensive recent review (Wirth, 2021), the vast majority of SMA patients (96\%) carry a homozygous deletion of exon 7 and 8 or exon 7 alone, while others have point mutations. Based on the severity of the disease, it is classified into six types. The SMA0 type is considered to comprise less than $1 \%$ of SMA patients, and newborns survive only a few days to weeks. The SMA1 type is the most common one, involving 50\% of the SMA cases and 1:10,000 live births. The children affected never sit up and usually die before the age of 2 years. The SMA2 patients (30\%) can sit up, but never walk and their survival is reduced similarly to SMA3a patients $(10 \%)$, who start to walk but finally lose ambulation at 18 months to 50 years. In two other subtypes, SMA3b (9\%) and SMA4 (less than 1\%) there are some walking impairments but occur later in life and the life span of the patients is not affected (Wirth, 2021).

Mutation in the Smn gene in mice is embryonically lethal. In humans, the severity of SMA depends on the number of copies of $S M N 2$, the second, almost identical gene, whose duplication is specific only for primates (Wirth et al., 2020). SMN2 differs from SMN1 only in five nucleotides. However, a point mutation in exon 7 results in its exclusion during alternative splicing, and the amount of the normal SMN protein is thus reduced. Because of that, the severity of SMA depends on the number of SMN2 copies in the SMA patients. The majority of SMA1 type patients have only two copies of the SMN2 gene $(73 \%)$, while about $7 \%$ have only one copy, and $20 \%$ have three copies. In contrast, $78 \%$ of SMA2 patients have three copies of the SMN2 gene, hence despite the mutation the amount of normal SMA protein generated is sufficient to allow the survival of patients to adulthood. Still, about $16 \%$ of SMA2 patients have only two SMN2 copies and therefore demonstrate more severe conditions. On the other hand, majority of the SMA3a and SMA3b patients have either three or four copies of $S M N 2$, and the persistent walking ability in $\mathrm{SMA} 3 \mathrm{~b}$ is thanks to a larger amount of SMA protein derived from four copies of the SMN2 gene present in $60 \%$ of these patients (Wirth, 2021).

The first effective genetic therapy for SMA was nusinersen, registered by FDA in 2016. Nusinersen (with brand name Spinraza), is an intrathecally delivered antisense oligonucleotide (for review see: Wirth et al., 2020). The injection route is due to the incapacity of the oligonucleotide to pass the blood-brain barrier which requires its direct delivery to the cerebrospinal fluid. Nusinersen is targeted to the splicing site of exon 7 . Its binding to pre-mRNA allows inclusion of exon 7 in the generated mRNA, by blocking recruitment of the splicing repressor hnRNP-A1 (Wirth, 2021). As a consequence, the amount of a proper SMA protein is significantly increased. Due to the limited half-life of the oligonucleotides, the therapy has to be repeated and the four injections per year are very costly, reaching $\$ 375,000$ per year (Table 4). Nevertheless, clinical trials have demonstrated the Nusinersen's effectiveness in patients of all SMA types and the therapy is registered both in the USA and Europe. Moreover, in many countries, including Poland, the treatment is covered by the state health insurance. According to a recent review, so far over 10,000 patients are treated worldwide (Wirth, 2021). When Nusinersen was applied to presymptomatic individuals who probably will develop SMA1 or SMA2, the study showed that treatment resulted in independent walking of almost 
90\% of patients (De Vivo et al., 2019; for review see: Mendell et al., 2021b).

In 2020, Risdiplam (Evrysdi; RG7916), an oral small molecule targeted therapy for SMA has been registered (Baranello et al., 2021). The final outcome achieved by Risdiplam is similar to Spinraza, because Risdiplam also increases the level of properly spliced mRNA of SMN2. Nevertheless, this is not genetic therapy but direct targeting of a mutation with small molecule. Risdiplam works by facilitating recruitment of the U1-snRNP particles to the splice donor site of intron 7 of the SMN2 gene (Wirth, 2021). This compound has to be taken daily and may offer an advantage over Spinraza due to the mode of delivery and the (future) cost. However, the price still remains high, being \$100,000-340 000/year, depending on the weight of the patient (Wirth, 2021).

In 2019, the FDA approved a classical gene therapy for SMA. Zolgensema (AVXS-101; onasemnogene aberparvovec), is an AAV9 type vector with the SMN1 gene driven by a strong chicken $\beta$-actin promoter (Mendell et al., 2017). It is delivered only once by a systemic intravenous injection, which makes this approach particularly attractive. The outcomes of Zolgensma application in children with SMA were spectacular in the phase I trial. In some cases, the children with SMA1 type not only survived beyond the previously not passed barrier of two years, but even gain the ability to walk (Wirth, 2021). Ongoing analysis confirms the effectiveness of this therapy (Mendell et al., 2021a). In Europe, Zolgensma is applied to patients with three or less copies of SMN2, but its application is limited to children of less than two years old and below $13.5 \mathrm{~kg}$ of weight in the USA and up to $21 \mathrm{~kg}$ in EU, due to the increased with age risk of gaining the AAV antibodies during typical infections occurring in children (Wirth, 2021). Zolgensma's serious limitation is the enormously high price of $\$ 2.1$ million which makes it the most expensive medicine.

The history of the development of the treatment of SMA demonstrates the power of genetic approaches. Several features of the SMN1 gene and the nature of the disease facilitated the establishment of this effective AAV therapy. The small size of the SMN1 gene allows its cloning into the AAV vector. Comparison with Duchenne muscular dystrophy (DMD), another common genetic disease, caused by mutations in the dystrophin gene on the $\mathrm{X}$-chromosome (for review see: (Loboda \& Dulak, 2020)) also shows how a variety in the disease mechanisms and the extent of the tissues to be affected hinders the development of effective therapies for DMD despite enormous knowledge generated. As described, for SMA there are now three registered medicines targeting the genetic cause of the disease. For DMD there are four registered antisense oligonucleotides - eteplirsen, casimersen and vitolarsen (Table 1), causing exon skipping and restoring the reading frame which allows partial restoration of a truncated dystrophin expression. However, their effectiveness is limited and the approval of them by the FDA was conditional (Loboda \& Dulak, 2020; Ferlini et al., 2021; Winkle et al., 2021). Moreover, as $\mathrm{SMN}$ is expressed from the SMN2 gene, correction of SMN2 splicing or gene transfer of SMN1 and consequently increased production of SMN protein does not induce an immune response, unlike in the case of DMD (for reviews see: Łoboda \& Dulak, 2020; Wirth, 2021).

Nevertheless, despite efficient means to increase the SMN protein level in SMA patients, the problems with the lack of SMN during fetal development and not sufficient level of this protein in other organs will undoubtedly have to be addressed when the treated patients will grow. The comorbidities in other organs, even with improvement in the central nervous system (targeted by the intrathecally delivered antisense oligonucleotides) have to be carefully monitored (Wirth, 2021). A very early initiation of treatment might be one of the key features here ((Ramos et al., 2019; Kong et al., 2021), as observed in a mouse model of SMA, in which elevation of the SMN levels during the first three days after birth prevented the disease, while treatment after day 5 was almost ineffective (Kariya et al., 2014). However, achieving a high level of the SMN protein for a long time might also cause problems, as toxic effects of high AAV9-SMN overexpression have been observed in aged mice (citation of conference presentation in Wirth, 2021). Elaborating on other therapies, relying on the disease-modifying pathways has to be also considered.

\section{ANTI-CANCER GENETIC THERAPIES}

At the beginning of gene therapy, adenoviral vectors have been considered as the very promising tools for treatment of diseases in which permanent expression is not required. This particularly concerns cancers, but these vectors have been also tested for other conditions, including the monogenic inherited diseases. A large capacity of the genome, which in the case of the so-called gutless vectors can harbor even up to $36 \mathrm{~kb}$ of nucleotides (Table 2) was regarded as the real advantage (Józkowicz \& Dulak, 2005). In addition, the relative ease in the production of large titers of adenoviral vectors makes them an excellent tool for the large-scale synthesis necessary for clinical trials. The concerns were related to the high inflammatory features of adenoviruses, which were dependent both on the preexisting immunity, as well as the necessity of using high viral titers which due to the expression of viral proteins exposed the patients to the risk of a systemic inflammatory reaction (for reviews see: Bessis et al., 2004; Liu \& Muruve, 2003).

Clinical gene therapy trials of cancer constitute the largest number of so far performed or ongoing gene therapies. Nevertheless, despite huge efforts, successful outcomes did not appear for a long time. Apparently, the complexity of cancer diseases and mechanisms hinders applications of these and similar approaches.

Besides the already mentioned p53-gene therapy of the head and neck cancer, among numerous studies which have not led so far to a formal approval is the suicide gene therapy for glioblastoma multiforme (GM), the most malignant brain tumor. The principle of suicide therapy relies on a localized delivery of the gene encoding the protein - an enzyme, which is able to metabolize the then intravenously delivered prodrug, converting it into an effective drug killing the cells in which the suicide gene is expressed (for review: (Sheikh et al., 2021)). In regard to GM, a very promising approach was a clinical trial coordinated by Seppo Yla-Herttuala from the University of Eastern Finland in Kuopio. After tumor resection, the adenoviral vector harboring a herpes virus thymidine kinase (HSV-TK) (Cerepro, sitimagene ceradenovec) was applied into the tumor area of the brain and the patients were injected with ganciclovir, the substrate for TK, which upon phosphorylation blocks DNA replication. The patients were concomitantly treated with temozolomide, the chemotherapy of choice in GM. Despite very promising initial clinical trials (Immonen et al., 2004), randomized phase 3 trials performed in several European countries did not show the real advantage of the HSV-TK gene therapy applied 
together with temozolomide over patients treated only with chemotherapy (Westphal et al., 2013), and this approach was not approved by EMA (Cerepro: Withdrawn application|European Medicines Agency (europa.eu)

The success of gene therapies in cancer is on the other hand exemplified in ex vivo approaches, aimed at boosting the patients' cell capacity to kill tumor cells. Genetic modification of the patients' $T$ lymphocytes with lentiviral vectors containing a gene encoding chimeric antigen receptors (CAR) arms these cells against the tumors (Milone \& O'Doherty, 2018). The chimeric receptors in the CAR-T therapies registered so far mostly target the CD19 protein common on the surface of B cells. This is the mechanism of action of Tisagenelecleucel (Kymriah) and axicabategene ciloleucel (Yescarta) for treatment of B-cell acute lymphoblastic leukemia and diffuse large Bcell lymphoma (a type of non-Hodgkin lymphoma), respectively. In 2020 and 2021, Tecartus (brexucabtagene autoleucel) for mantle cell lymphoma, Abecma (idecabtagene vicleucel) for multiple myeloma and Breyanzi (lisocabtagene maraleucel) for large B-cell lymphoma were approved (Ellis et al., 2021; Munshi et al., 2021) (Table 1, Table 2). Abecma targets a B-cell maturation antigen (BCMA), unlike the other CAR-T cell therapies registered so far, which target the CD19 protein.

Gene therapy of cancer can be also executed by viruses able to fully replicate only in the tumor cells. These oncolytic viruses, due to some mutations, cannot perform the full cycle in normal cells, but they can effectively replicate and finally kill the tumor cells lacking e.g. the correct p53 gene (Kaufman et al., 2016). Although such an approach is not classical gene therapy, the fact that the vectors can be additionally manipulated makes them an example of genetic therapy. In Europe and the USA, in 2015, the IMLYGIC (T-VEC, talimogene laherparepvec) has been registered. This is a herpes simplex virus additionally harboring the CSF3 gene (coding for granulocyte-macrophage colony-stimulating factor; GM-CSF) which is applied for unresectable melanoma recurrent after initial injection (for review see: Koch et al., 2020). However, the real efficacy of this therapy still needs verification (Larocca et al., 2020).

\section{RNA AS THERAPEUTICS}

The field of RNA was raised to a great importance in the 21 st century. Discovery of efficient mechanisms of gene silencing by siRNA, followed by elucidation of the important roles of microRNAs, created hopes for applications of these strategies for therapeutic purposes. However, despite long efforts, clinical applications were limited until recent years, when the siRNA targeting the transthyretin amyloid mRNA in hereditary variant transthyretin amyloidosis patients (hATTRv) was registered in 2018 by the FDA and EMA. Patisaran (Urits et al., 2020) can be used in patients suffering from this very rare disease affecting about 5,000-10,000 people worldwide. Of note, for the hATTR treatment an antisense oligonucleotide inotersen has been also recently registered (Benson et al., 2018) (Table 1). Currently, a few other siRNA therapeutics have been approved by the EMA and/or FDA. Among them are givosiran for acute hepatic porphyria, inclisiran for hereditary familial hypercholesterolemia, and lumasiran for primary hyperoxaluria type 1 (Table 1) (for review see: (Winkle et al., 2021)). And, as is very well known, the COVID-19 pandemic demonstrates the utility of mRNA anti-SARS-CoV-2 vaccines, as well as, of course, those based on adenoviral vectors (for review see: Sadarangani et al., 2021).

\section{PROMISING EXAMPLES OF EXPERIMENTAL CLINICAL TRIALS OF GENE THERAPY}

\section{Hemophilia}

Hemophilia is the most common X-linked disease. In hemophilia $A$, the inability of blood clotting is due to the lack of a proper gene for factor VIII, while in hemophilia B for factor IX. The factor IX, due to the size of its cDNA, is a good candidate for AAV-based gene therapies. Clinical studies, preceded by long-term experiments in dogs (Manno et al., 2006), have demonstrated the effectiveness of intravenous administration of AAV with factor IX cDNA to target the liver of hemophilia B patients (Manno et al., 2006; Nathwani et al., 2011; Nathwani et al., 2014; George et al., 2017). However, problems appear with the pre-existing antibodies to AAV capsids. Similar drawbacks can be encountered in the treatment of hemophilia A, where additionally due to the very large size of factor VIII cDNA, only its truncated form can be applied by AAVs (Rangarajan et al., 2017).

\section{Epidermolysis bullosa (EB)}

EB comprises several severe rare diseases in which the lack of various proteins, such as collagen XVII or laminins, causes continuous detachment of the epidermis associated with severe, often extreme suffering of the patients. There are no effective treatments and together with continuous pain, as well as a permanent risks of infections, some patients are under the threat of development of cancer (for review see: De Luca et al., 2019).

This is the case in junctional EB in which a mutation in the $L A M B 3$ gene results in the lack of laminin 332. In the previous decade, the Italian scientists, led by Michele De Luca and Graziella Pellegrini, performed an initial trial in an adult EB patient, whose epidermal stem cells were isolated from the undamaged part of the skin and modified ex vivo with retroviral vector harboring the LAMB3 gene (Mavilio et al., 2006). The modified, cured epidermis was cultured and small pieces were placed on the damaged skin area of the patient where they adhered and partially restored the healthy skin and persisted for more than six years (De Rosa et al., 2014).

In 2015, the same group of Italian researchers working together with German clinicians saved the life and restored the healthy skin in a 7-year old boy suffering from this disease. The conditions of this patient before treatment were very poor and he was kept in a pharmacological coma due to the damage of almost $70 \%$ of his skin and recurrent sepsis caused by infections with Staphylococcus aureus and Pseudomonas aeruginosa. Large fragments of healthy epidermis obtained from the patient's epidermal stem cells modified with a retroviral vector harboring proper $L A M B 3$ gene were generated in the laboratory and placed on the extremely affected body of the boy. The spectacular results demonstrate almost total healing of the skin and two years after the treatment the boy was able to attend school and participate in sport exercisies, an activity not available for children with this severe disease (Hirsch et al., 2017). Five years after treatment, the boy's conditions are very good (Prof. Graziella Pellegrini, personal communication). 


\section{Lysosomal storage diseases}

Another recent example can be the lentivirus-mediated gene therapy for the ultra-rare Fabry disease, a lysosomal disorder in which patients lacking the $\alpha$-galactosidase A $(\alpha-$ Gal A) enzyme develop a progressive lysosomal accumulation of globotriaosylceramide, which besides numerous painful syndromes finally leads to a stroke and myocardial infarction. In a recent gene therapy clinical trial, five patients have been treated with autologous $\mathrm{CD} 4^{+}$cells transduced with lentiviral vector harboring the $\alpha-G a l$ sequence. Interestingly, within a week all patients started to produce a near-normal level of the enzyme and the effects have already persisted in at least one patient for three years post-infusion. Three patients decided to discontinue the enzyme replacement therapy (Khan et al., 2021).

Several other lysosmal storage diseases (LSD) are also the target of pre-clinical and in some cases early clinical trials of gene therapy. As in the case of the mentioned above metachromatic leukodystrophy (Tucci et al., 2021) and Fabry disease (Khan et al., 2021), clinical studies so far concentrate on the ex vivo gene therapy of autologous hematopoietic progenitor cells transudced with lentiviral vectors harboring a relevant therapeutic gene. Recent comprehensive reviews ((Tucci et al., 2021; Massaro et al., 2021) describe in more details the trials in which the CD34+ cells are to be transduced with $\mathrm{N}$-sulfoglucosamine sulfohydrolase cDNA for treatment of mucopolysacharidosis type III, $\alpha$-L-iduronidase for the Hurler variant of mucopolisacharidosis type I, $\beta$-glucocerebrosidase cDNA for the Gaucher disease and the cystinosin gene for cystinosis. Some of the LSDs are also considered as targets for gene editing strategies (Massaro et al., 2021) and a first one was initiated in a patient with type II mucopolisacharidosis (the Hunter's syndrome) (see: First in vivo human genome editing trial, Nature Biotechnology, January 2018)

\section{GENE EDITING}

Currently, gene editing approaches particularly concentrate on the application of CRISPR/Cas9, due to the simplicity of designing the tools to specifically target a gene to mutate or repair it. In contrast to the zinc-finger or TALEN strategies, which historically preceded CRISPR/Cas9 (Wood et al., 2011), the latter does not require the design of the protein to target the gene of interest. The ease to program and synthesize the single guide RNAs (sgRNAs) and relative simplicity to deliver them together with the Cas9 enzyme (they can be both transduced with the AAV vectors, which makes them suitable for in vivo approaches) led relatively quickly to initiation of clinical trials which will be discussed later. Nevertheless, historically, the first clinical gene editing approach was performed with application of the zinc-finger nuclease strategy (ZFN) (Tebas et al., 2014).

ZFN consists of a tandem array of $\mathrm{Cys}_{2} \mathrm{His}_{2}$ zinc fingers, combined with the FokI nuclease. Each tandem array recognizes approximately three base pairs of DNA. Importantly, the FokI nuclease, which is bacterial type II restriction endonuclease, does not recognize any specific DNA sequence but it gains the cutting specificity when it dimerizes. Accordingly, the properly designed zinc finger proteins (ZFP) target the specific regions on the opposite DNA strands and allow dimerization of FokI connected with ZFP. Cutting of DNA initiates the repairing mechanisms and the DNA can be corrected either by homologous recombination (HR), when the correct sequence homologous to the targeted region is delivered to the cells, or by non-homologous end joining (NHEJ). HR is mostly applied when the aim is to repair the mutation, and NHEJ is applied when a mutation in the sequence is desired (for review see: Urnov et al., 2010).

Observation of the so-called "Berlin patient", in whom the bone marrow transplantation for treatment of leukemia also caused a remission of an HIV infection, created the background for gene editing intervention in AIDS patients. In this patient, the transplanted bone marrow was derived from the donor who had a mutation in the CCR5 gene. The deletion of $32 \mathrm{bp}$ in CCR5 sequence did not impair the donor's $\mathrm{CD}^{+} \mathrm{T}$-cell function, but it rendered these cells resistant to infection to HIV and led to the diminishment and disappearance of the HIV viral load (Zou et al., 2013).

This observation was the rationale for a clinical trial in 12 AIDS patients, whose $\mathrm{T}$ cells have been ex vivo treated with adenoviral vector-based zinc-fingers to mutate the CCR5 (Tebas et al., 2014). The infusion of such edited cells resulted in a quick increase in the number of CD4 $\mathrm{T}$ cells which persisted in the circulation for almost one year and the blood level of HIV DNA decreased in most of the patients (Tebas et al., 2014). Recently, the same group has performed a similar trial in which the CCR 5 in $\mathrm{T}$ lymphocytes has been targeted by CRISPR/ Cas9 (Tebas et al., 2021). However, mixed results of the studies indicate that although it has a strong biological rationale, its effectiveness needs improvement. Of note, the FokI enzyme used in ZFN and TALENs was introduced by Wacław Szybalski, Anna Podhajska and S.C. $\mathrm{Kim}$ as the universal restriction enzyme (Podhajska \& Szybalski, 1985; Kim et al., 1988), and then proved useful in the Human Genome Project.

The simplicity of the CRISPR/Cas9 editing makes it rather an obvious choice for future clinical developments. In 2020, a first clinical trial has been initiated in patients suffering from Leber's congenital amaurosis type 10 (LCA10), the most common form of LCA (about $30 \%$ ), caused by a mutation in the CEP290 gene (Ledford, 2020). This is a different form than RPE65-LCA, which can be now treated with Luxturna, as discussed above. The CEP290 gene is much bigger than RPE65 (the cDNA for CEP290 is 8000 nucleotides) (Burnight et al., 2014), and hence the AAV vectors cannot be used to deliver it to the retina (Ledford, 2020). It is hoped that with the CRISPR/Cas9 approach, correction of the mutation should restore the proper level of CEP290 in photoreceptors.

Recently, the first results of the clinical application of CRISPR/Cas9 strategy for the treatment of one patient with transfusion-dependent $\beta$-thalassemia and one with SCD have been published. Although the mutations in both diseases are different, both concern the $\beta$-globin gene. The same gene editing strategy could be applied in both diseases, as the target for CRISPR/Cas9 can be the $B C L 11 A$ gene - an erythroid-specific enhancer repressing $\gamma$-globin expression, hence switching off this fetal hemoglobin production after birth. In these two patients, their $\mathrm{CD} 34^{+}$cells have been ex vivo targeted with CRISPR/Cas9 directed to BCL11A to mutate it and in this way to abolish its expression. The patients received an infusion of their own edited cells after myeloablation and one year later, both patients demonstrated a high level of BCL11A edition in the bone marrow and blood. Importantly, an increase in fetal hemoglobin, transfusion independence, and elimination of vaso-occlusive 
episodes, the latter in the patient with SCD, have been observed (Frangoul et al., 2021).

Moreover, gene editing can allow correction of mutation in the $\beta$-globin gene of sickle cell disease patients, although the low efficacy of homology-directed repair in HSPC must be overcome. A new approach of "base editing" offers an additional promise, in which even the silencing of BCL11A can be combined with the repair of the globin mutation (Zeng et al., 2020)

In another study published at the same time, Esrick et. al have used the shRNA delivered by lentiviral vectors to $\mathrm{CD}_{34}{ }^{+}$cells to silence BCL11A. Six SCD patients have been treated and followed up for at least six months, during which a robust induction of fetal hemoglobin was observed and clinical manifestations of SCD were reduced or absent (Esrick et al., 2021).

\section{SUMMARY}

Since Elisabeth and Wacław Szybalski performed the first permanent modification of mamalian cells thanks not only to the brave and genious idea, but also a little bit of luck always necessary in breakthrough experiments, numerous approaches have been established, making genetic modifications not only the obvious and indispensable research tools, but also convincingly proving its medical rationale and utility. Correction of the HPRT-deficient cells with DNA isolated from normal cells was possible thanks to the high content of calcium ions, which neutralized the negative charge of DNA and allowed its entrance into the HPRT-negative cells. In the late 60ties and 70ties of the 20th century, calcium chloride became the routine tool for nonviral gene delivery. The development of numerous other neutralizing vehicles, like cationic liposomes, polyamines and dendrimers allow the effective transfection of cells in vitro. Recently, application of liposomes for delivery of RNA antiSARS-CoV-2 vaccines has demonstrated a large utility of this type of in vivo gene administration. The success of clinical gene therapy has been possible thanks to the enormous work of basic science researchers, elucidating the nature of viruses and modifying their properties for safe clinical applications. The potential for therapeutic genetic manipulation has been recently spectacularly increased thanks to the gene-editing technology. Due to their simplicity, the CRISPR/Cas9 based strategies are the first choice, but one has to remember that application of the universal FokI restriction enzyme, applied for the first time by Anna Podhajska and Wacław Szybalski to manipulate bacterial genome, has opened the possibility for use of the FokI protein in combination with zinc fingers or TALEN to modify the mammalian cells. Wacław Szybalski's ideas and experiments were initiated at the time when the discovery of DNA structure was accepted and awarded with a Nobel prize in 1962, and add enormously to these seminal scientific discoveries. Establishing the background for gene manipulation to treat diseases can be considered as one of the greatest achievements of science. The legacy of Wacław Szybalski should stay with the growing knowledge and application of molecular biology.

\section{Acknowledgements}

The comments of Prof. Alicja Józkowicz, Dr Agnieszka Łoboda, Dr Agnieszka Jażwa-Kusior, Dr Jacek Stępniewski, Dr Krzysztof Szade and Ms. Izabela Kraszewska, MSc, are highly appreciated. The help of Ms. Joanna Strzęp-Knapiak in figure preparation and editorial help of Ms. Joanna Uchto-Bajołek is acknowledged. Currently, the author's research on gene therapy technologies and stem cells is supported by grants MAESTRO 10 (2018/30/A/NZ3/00412) from the National Science Center (NCN), CISTEM MSCA RISE (Z/H2O/00023 from H2020 program (grant agreement No. 778354) and NMJ-on-a-chip (UMO-2019/01/Y/NZ3/00012) from JPND initiative (Horizon 2020) and NCN. The author reports no conflict of interest.

\section{REFERENCES}

Baranello G, Darras BT, Day JW, Deconinck N, Klein A, Masson R, Mercuri E, Rose K, El-Khairi M, Gerber M, Gorni K, Khwaja O, Kletzl H, Scalco RS, Seabrook T, Fontoura P, Servais L, FIREFISH Working Group (2021) Risdiplam in Type 1 Spinal Muscular Atrophy. N Engl J Med 384: 915-923. https://doi.org/10.1056/ NEJMoa2009965

Belmadi N, Midoux P, Loyer P, Passirani C, Pichon C, Le Gall T, Jaffres PA, Lehn P, Montier T (2015) Synthetic vectors for gene delivery: An overview of their evolution depending on routes of administration. Biotechnol J 10: 1370-1389. https://doi.org/10.1002/ biot.201400841

Benson MD, Waddington-Cruz M, Berk JL, Polydefkis M, Dyck PJ, Wang AK, Planté-Bordeneuve V, Barroso FA, Merlini G, Obici L, Scheinberg M, Brannagan TH, Litchy WJ, Whelan C, Drachman BM, Adams D, Heitner SB, Conceição I, Schmidt HH, Vita G, Campistol JM, Gamez J, Gorevic PD, Gane E, Shah AM, Solomon SD, Monia BP, Hughes SG, Kwoh TJ, McEvoy BW, Jung SW, Baker BF, Ackermann EJ, Gertz MA, Coelho T (2018) Inotersen Treatment for Patients with Hereditary Transthyretin Amyloidosis. $N$ Engl J Med 379: 22-31. https://doi.org/10.1056/NEJMoa1716793

Bessis N, GarciaCozar FJ, Boissier MC (2004) Immune responses to gene therapy vectors: influence on vector function and effector mechanisms. Gene Ther 11 (Suppl 1): S10-S17. https://doi. org/10.1038/sj.gt.3302364

Biffi A, Montini E, Lorioli L, Cesani M, Fumagalli F, Plati T, Baldoli C, Martino S, Calabria A, Canale S, Benedicenti F, Vallanti G, Biasco L, Leo S, Kabbara N, Zanetti G, Rizzo WB, Mehta NAL, Cicalese MP, Casiraghi M, Boelens JJ, Del Carro U, Dow DJ, Schmidt M, Assanelli A, Neduva V, Di Serio C, Stupka E, Gardner J, von Kalle C, Bordignon C, Ciceri F, Rovelli A, Roncarolo MG, Aiuti A, Sessa M, Naldini L (2013) Lentiviral hematopoietic stem cell gene therapy benefits metachromatic leukodystrophy. Science 341: 1233158. https://doi.org/10.1126/science.1233158

Blaese RM, Culver KW, Miller AD, Carter CS, Fleisher T, Clerici M, Shearer G, Chang L, Chiang Y, Tolstoshev P, Greenblatt JJ, Rosenberg SA, Klein H, Berger M, Mullen CA, Ramsey WJ, Muul L, Morgan RA, Anderson WF (1995) T lymphocyte-directed gene therapy for ADA-SCID: initial trial results after 4 years. Science 270: 475-480. https://doi.org/10.1126/science.270.5235.475

Braga L, Ali H, Secco I, Giacca M (2021) Non-coding RNA therapeutics for cardiac regeneration. Cardiovasc Res 117: 674-693. https:// doi.org/10.1093/cvr/cvaa071

Braun CJ, Boztug K, Paruzynski A, Witzel M, Schwarzer A, Rothe M, Modlich U, Beier R, Göhring G, Steinemann D, Fronza R, Ball CR, Haemmerle R, Naundorf S, Kühlcke K, Rose M, Fraser C, Mathias L, Ferrari R, Abboud MR, Al-Herz W, Kondratenko I, Maródi L, Glimm H, Schlegelberger B, Schambach A, Albert MH, Schmidt $\mathrm{M}$, von Kalle C, Klein C (2014) Gene therapy for Wiskott-Aldrich syndrome - long-term efficacy and genotoxicity. Sci Transl Med 6: 227ra33. https://doi.org/10.1126/scitranslmed.3007280

Burnight ER, Wiley LA, Drack AV, Braun TA, Anfinson KR, Kaalberg EE, Halder JA, Affatigato LM, Mullins RF, Stone EM, Tucker BA (2014) CEP290 gene transfer rescues Leber congenital amaurosis cellular phenotype. Gene Ther 21: 662-672. https://doi.org/10.1038/ gt.2014.39

Cannatà A, Ali H, Sinagra G, Giacca M (2020) Gene therapy for the heart lessons learned and future perspectives. Circ Res 126: 1394 1414. https://doi.org/10.1161/CIRCRESAHA.120.315855

Cavazzana-Calvo M, Hacein-Bey S, de Saint Basile G, Gross F, Yvon E, Nusbaum P, Selz F, Hue C, Certain S, Casanova JL, Bousso P, Deist FL, Fischer A (2000) Gene therapy of human severe combined immunodeficiency (SCID)-X1 disease. Science 288: 669-672. https://doi.org/10.1126/science.288.5466.669

Chen HY, Lehmann OJ, Swaroop A (2021) Genetics and therapy for pediatric eye diseases. EBioMedicine 67: 103360. https://doi. org/10.1016/j.ebiom.2021.103360

Cicalese MP, Ferrua F, Castagnaro L, Pajno R, Barzaghi F, Giannelli S, Dionisio F, Brigida I, Bonopane M, Casiraghi M, Tabucchi A, Carlucci F, Grunebaum E, Adeli M, Bredius RG, Puck JM, Stepensky P, Tezcan I, Rolfe K, De Boever E, Reinhardt RR, Appleby J, Ciceri F, Roncarolo MG, Aiuti A (2016) Update on the 
safety and efficacy of retroviral gene therapy for immunodeficiency due to adenosine deaminase deficiency. Blood 128: 45-54. https:// doi.org/10.1182/blood-2016-01-688226

Cideciyan AV, Jacobson SG, Ho AC, Garafalo AV, Roman AJ, Sumaroka A, Krishnan AK, Swider M, Schwartz MR, Girach A (2021) Durable vision improvement after a single treatment with antisense oligonucleotide sepofarsen: a case report. Nat Med 27: 785-789. https://doi.org/10.1038/s41591-021-01297-7

Culver K, Cornetta K, Morgan R, Morecki S, Aebersold P, Kasid A, Lotze M, Rosenberg SA, Anderson WF, Blaese RM (1991) Lymphocytes as cellular vehicles for gene therapy in mouse and man. Proc Natl Acad Sci U S A 88: 3155-3159. https://doi.org/10.1073/ pnas.88.8.3155

da Cruz L, Fynes K, Georgiadis O, Kerby J, Luo YH, Ahmado A, Vernon A, Daniels JT, Nommiste B, Hasan SM, Gooljar SB, Carr A-JF, Vugler A, Ramsden CM, Bictash M, Fenster M, Steer J, Harbinson T, Wilbrey A, Tufail A, Feng G, Whitlock M, Robson AG Holder GE, Sagoo MS, Loudon PT, Whiting P, Coffey PJ (2018) Phase 1 clinical study of an embryonic stem cell-derived retinal pigment epithelium patch in age-related macular degeneration. Nat Biotechnol 36: 328-337. https://doi.org/10.1038/nbt.4114

De Luca M, Aiuti A, Cossu G, Parmar M, Pellegrini G, Robey PG (2019) Advances in stem cell research and therapeutic development. Nat Cell Biol 21: 801-811. https://doi.org/10.1038/s41556-0190344-z

De Ravin SS, Wu X, Moir S, Anaya-O’Brien S, Kwatemaa N, Littel P, Theobald N, Choi U, Su L, Marquesen M, Hilligoss D, Lee J, Buckner CM, Zarember KA, O'Connor G, McVicar D, Kuhns D, Throm RE, Zhou S, Notarangelo LD, Hanson IC, Cowan MJ, Kang E, Hadigan C, Meagher M, Gray JT, Sorrentino BP, Malech HL, Kardava L (2016) Lentiviral hematopoietic stem cell gene therapy for X-linked severe combined immunodeficiency. Sci Transl Med 8: 335ra57. https://doi.org/10.1126/scitranslmed.aad8856

De Rosa L, Carulli S, Cocchiarella F, Quaglino D, Enzo E, Franchini E, Giannetti A, De Santis G, Recchia A, Pellegrini G, De Luca M (2014) Long-term stability and safety of transgenic cultured epidermal stem cells in gene therapy of junctional epidermolysis bullosa. Stem Cell Reports 2: 1-8. https://doi.org/10.1016/j.stemcr.2013.11.001

De Vivo DC, Bertini E, Swoboda KJ, Hwu W-L, Crawford TO, Finkel RS, Kirschner J, Kuntz NL, Parsons JA, Ryan MM, Butterfield RJ, Topaloglu H, Ben-Omran T, Sansone VA, Jong Y-J, Shu F, Staropoli JF, Kerr D, Sandrock AW, Stebbins C, Petrillo M, Braley G, Johnson K, Foster R, Gheuens S, Bhan I, Reyna SP, Fradette S, Farwell W, NURTURE Study Group (2019) Nusinersen initiated in infants during the presymptomatic stage of spinal muscular atrophy: Interim efficacy and safety results from the Phase 2 NURTURE study. Neuromuscul Disord 29: 842-856. https://doi.org/10.1016/j. nmd. 2019,09,007

Dunbar CE, High KA, Joung JK, Kohn DB, Ozawa K, Sadelain M (2018) Gene therapy comes of age. Science 359: eaan4672. https:// doi.org/10.1126/science.aan4672

Eichler F, Duncan C, Musolino PL, Orchard PJ, De Oliveira S, Thrasher AJ, Armant M, Dansereau C, Lund TC, Miller WP, Raymond GV, Sankar R, Shah AJ, Sevin C, Gaspar HB, Gissen P, Amartino H, Bratkovic D, Smith NJC, Paker AM, Shamir E, O'Meara T, Davidson D, Aubourg P, Williams DA (2017) Hematopoietic stem-cell gene therapy for cerebral adrenoleukodystrophy. $N$ Engl I Med 377: 1630-1638. https://doi.org/10.1056/NEJMoa1700554

Ellis GI, Sheppard NC, Riley JL (2021) Genetic engineering of T cells for immunotherapy. Nat Rev Genet 22: 427-447. https://doi. org/10.1038/s41576-021-00329-9

Esrick EB, Lehmann LE, Biffi A, Achebe M, Brendel C, Ciuculescu MF, Daley H, MacKinnon B, Morris E, Federico A, Abriss D, Boardman K, Khelladi R, Shaw K, Negre H, Negre O, Nikiforow S, Ritz J, Pai S-Y, London WB, Dansereau C, Heeney MM, Armant M, Manis JP, Williams DA (2021) Post-transcriptional genetic silencing of BCL11A to treat sickle cell disease. N Engl J Med 384: 205-215. https://doi.org/10.1056/NEJMoa2029392

Ferlini A, Goyenvalle A, Muntoni F (2021) RNA-targeted drugs for neuromuscular diseases. Science 371: 29-31. https://doi.org/10.1126/ science.aba4515

Ferrari G, Thrasher AJ, Aiuti A (2021) Gene therapy using haematopoietic stem and progenitor cells. Nat Rev Genet 22: 216-234. https://doi.org/10.1038/s41576-020-00298-5

Ferrua F, Aiuti A (2017) Twenty-five years of gene therapy for ADASCID: From bubble babies to an approved drug. Hum Gene Ther 28 972-981. https://doi.org/10.1089/hum.2017.175

First in vivo human genome editing trial (2018) Nat Biotechnol 36: 5. https://doi.org/10.1038/nbt0118-5b

Frangoul H, Altshuler D, Cappellini MD, Chen Y-S, Domm J, Eustace BK, Foell J, de la Fuente J, Grupp S, Handgretinger R, Ho TW, Kattamis A, Kernytsky A, Lekstrom-Himes J, Li AM, Locatelli F, Mapara MY, de Montalembert M, Rondelli D, Sharma A, Sheth S, Soni S, Steinberg MH, Wall D, Yen A, Corbacioglu S (2021) CRIS-
PR-Cas9 gene editing for sickle cell disease and $\beta$-thalassemia. $N$ Engl J Med 384: 252-260. https://doi.org/10.1056/NEJMoa2031054 Gaspar HB, Parsley KL, Howe S, King D, Gilmour KC, Sinclair J, Brouns G, Schmidt M, Von Kalle C, Barington T, Jakobsen MA, Christensen HO, Al Ghonaium A, White HN, Smith JL, Levinsky RJ, Ali RR, Kinnon C, Thrasher AJ (2004) Gene therapy of $\mathrm{X}$-linked severe combined immunodeficiency by use of a pseudotyped gammaretroviral vector. Lancet 364: 2181-2187. https://doi. org/10.1016/S0140-6736(04)17590-9

George LA, Sullivan SK, Giermasz A, Rasko JEJ, Samelson-Jones BJ, Ducore J, Cuker A, Sullivan LM, Majumdar S, Teitel J, McGuinn CE, Ragni MV, Luk AY, Hui D, Wright JF, Chen Y, Liu Y, Wachtel K, Winters A, Tiefenbacher S, Arruda VR, van der Loo JCM, Zelenaia O, Takefman D, Carr ME, Couto LB, Anguela XM, High KA (2017) Hemophilia B Gene Therapy with a High-Specific-Activity Factor IX Variant. N Engl J Med 377: 2215-2227. https://doi. org/10.1056/NEJMoa1708538

Giacca M, Zacchigna S (2012) Virus-mediated gene delivery for human gene therapy. J Control Release 161: 377-388. https://doi. org/10.1016/j.jconrel.2012.04.008

Guo W, Song H (2018) Development of gene therapeutics for head and neck cancer in China: From bench to bedside. Hum Gene Ther 29: 180-187. https://doi.org/10.1089/hum.2017.230

Hacein-Bey-Abina S, Hauer J, Lim A, Picard C, Wang GP, Berry CC, Martinache C, Rieux-Laucat F, Latour S, Belohradsky BH, Leiva L, Sorensen R, Debré M, Casanova JL, Blanche S, Durandy A, Bushman FD, Fischer A, Cavazzana-Calvo M (2010) Efficacy of gene therapy for X-linked severe combined immunodeficiency. $N$ Engl J Med 363: 355-364. https://doi.org/10.1056/NEJMoa1000164

Hacein-Bey-Abina S, Von Kalle C, Schmidt M, McCormack MP, Wulffraat N, Leboulch P, Lim A, Osborne CS, Pawliuk R, Morillon E, Sorensen R, Forster A, Fraser P, Cohen JI, de Saint Basile G, Alexander I, Wintergerst U, Frebourg T, Aurias A, Stoppa-Lyonnet D, Romana S, Radford-Weiss I, Gross F, Valensi F, Delabesse E, Macintyre E, Sigaux F, Soulier J, Leiva LE, Wissler M, Prinz C, Rabbitts TH, Le Deist F, Fischer A, Cavazzana-Calvo M (2003) LMO2-associated clonal $\mathrm{T}$ cell proliferation in two patients after gene therapy for SCID-X1. Science 302: 415-419. https://doi.org/10.1126/science. 1088547

High KA, Roncarolo MG (2019) Gene Therapy. N Engl J Med 381: 455-464. https://doi.org/10.1056/NEJMra1706910

Hirsch T, Rothoeft T, Teig N, Bauer JW, Pellegrini G, De Rosa L, Scaglione D, Reichelt J, Klausegger A, Kneisz D, Romano O, Secone Seconetti A, Contin R, Enzo E, Jurman I, Carulli S, Jacobsen F, Luecke T, Lehnhardt M, Fischer M, Kueckelhaus M, Quaglino D, Morgante M, Bicciato S, Bondanza S, De Luca M (2017) Regeneration of the entire human epidermis using transgenic stem cells. Nature 551: 327-332. https://doi.org/10.1038/nature24487

Hoggatt J (2016) Gene therapy for "Bubble Boy" disease. Cell 166: 263. https://doi.org/10.1016/j.cell.2016.06.049

Immonen A, Vapalahti M, Tyynelä K, Hurskainen H, Sandmair A, Vanninen R, Langford G, Murray N, Ylä-Herttuala S (2004) AdvHSV-tk gene therapy with intravenous ganciclovir improves survival in human malignant glioma: a randomised, controlled study. Mol Ther 10: 967-972. https://doi.org/10.1016/j.ymthe.2004.08.002

Jazwa A, Florczyk U, Jozkowicz A, Dulak J (2013) Gene therapy on demand: site specific regulation of gene therapy. Gene 525: 229-238. https://doi.org/10.1016/j.gene.2013.03.093

Jones RJ, DeBaun MR (2021) Leukemia after gene therapy for sickle cell disease: insertional mutagenesis, busulfan, both or neither. Blood Jun3. https://doi.org/10.1182/blood.2021011488

Józkowicz A, Dulak J (2005) Helper-dependent adenoviral vectors in experimental gene therapy. Acta Biochim Pol 52: 589-599

Kariya S, Obis T, Garone C, Akay T, Sera F, Iwata S, Homma S, Monani UR (2014) Requirement of enhanced Survival Motoneuron protein imposed during neuromuscular junction maturation. I Clin Invest 124: 785-800. https://doi.org/10.1172/JCI72017

Kaufman HL, Kohlhapp FJ, Zloza A (2016) Oncolytic viruses: a new class of immunotherapy drugs. Nat Rev Drug Discov 15: 660. https:// doi.org/10.1038/nrd.2016.178

Kelley RE, Andersson HC (2014) Disorders of purines and pyrimidines. Handb Clin Neurol 120: 827-838. https://doi.org/10.1016/ B978-0-7020-4087-0.00055-3

Khan A, Barber DL, Huang J, Rupar CA, Rip JW, Auray-Blais C, Boutin M, O'Hoski P, Gargulak K, McKillop WM, Fraser G, Wasim S, LeMoine K, Jelinski S, Chaudhry A, Prokopishyn N, Morel CF, Couban S, Duggan PR, Fowler DH, Keating A, West ML, Foley $\mathrm{R}$, Medin JA (2021) Lentivirus-mediated gene therapy for Fabry disease. Nat Commun 12: 1178. https://doi.org/10.1038/s41467-02121371-5

Kim SC, Podhajska AJ, Szybalski W (1988) Cleaving DNA at any predetermined site with adapter-primers and class-IIS restriction enzymes. Science 240: 504-506. https://doi.org/10.1126/science. 2833816 
Koch MS, Lawler SE, Chiocca EA (2020) HSV-1 oncolytic viruses from bench to bedside: An overview of current clinical trials. Cancers (Basel) 12: E3514. https://doi.org/10.3390/cancers12123514

Kohn DB, Booth C, Kang EM, Pai S-Y, Shaw KL, Santilli G, Armant M, Buckland KF, Choi U, De Ravin SS, Dorsey MJ, Kuo CY, Leon-Rico D, Rivat C, Izotova N, Gilmour K, Snell K, Dip JX-B, Darwish J, Morris EC, Terrazas D, Wang LD, Bauser CA, Paprotka T, Kuhns DB, Gregg J, Raymond HE, Everett JK, Honnet G, Biasco L, Newburger PE, Bushman FD, Grez M, Gaspar HB, Williams DA, Malech HL, Galy A, Thrasher AJ, Net4CGD consortium (2020) Lentiviral gene therapy for X-linked chronic granulomatous disease. Nat Med 26: 200-206. https://doi.org/10.1038/s41591-0190735-5

Kohn DB, Booth C, Shaw KL, Xu-Bayford J, Garabedian E, Trevisan V, Carbonaro-Sarracino DA, Soni K, Terrazas D, Snell K, Ikeda A, Leon-Rico D, Moore TB, Buckland KF, Shah AJ, Gilmour KC, De Oliveira S, Rivat C, Crooks GM, Izotova N, Tse J, Adams S, Shupien S, Ricketts H, Davila A, Uzowuru C, Icreverzi A, Barman P, Campo Fernandez B, Hollis RP, Coronel M, Yu A, Chun KM, Casas CE, Zhang R, Arduini S, Lynn F, Kudari M, Spezzi A, Zahn M, Heimke R, Labik I, Parrott R, Buckley RH, Reeves L, Cornetta K, Sokolic R, Hershfield M, Schmidt M, Candotti F, Malech HL, Thrasher AJ, Gaspar HB (2021) Autologous ex vivo lentiviral gene therapy for adenosine deaminase deficiency. N Engl J Med 384: 2002-2013. https://doi.org/10.1056/NEJMoa2027675

Kohn LA, Kohn DB (2021) Gene therapies for primary immune deficiencies. Front Immunol 12: 648951. https://doi.org/10.3389/fimmu.2021.648951

Kong L, Valdivia DO, Simon CM, Hassinan CW, Delestrée N, Ramos DM, Park JH, Pilato CM, Xu X, Crowder M, Grzyb CC, King ZA, Petrillo M, Swoboda KJ, Davis C, Lutz CM, Stephan AH, Zhao X, Weetall M, Naryshkin NA, Crawford TO, Mentis GZ, Sumner CJ (2021) Impaired prenatal motor axon development necessitates early therapeutic intervention in severe SMA. Sci Transl Med 13: eabb6871. https://doi.org/10.1126/scitranslmed.abb6871

Korpela H, Järveläinen N, Siimes S, Lampela J, Airaksinen J, Valli K, Turunen M, Pajula J, Nurro J, Ylä-Herttuala S (2021) Gene therapy for ischaemic heart disease and heart failure. I Intern Med Ahead of print. https://doi.org/10.1111/joim.13308

Kraszewska I, Tomczyk M, Andrysiak K, Biniecka M, Geisler A, Fechner H, Zembala M, Stępniewski J, Dulak J, Jaźwa-Kusior A (2020) Variability in Cardiac miRNA-122 Level Determines Therapeutic Potential of miRNA-Regulated AAV Vectors. Mol Ther Methods Clin Dev 17: 1190-1201. https://doi.org/10.1016/j.omtm.2020.05.006

Larocca CA, LeBoeuf NR, Silk AW, Kaufman HL (2020) An update on the role of talimogene laherparepvec (T-VEC) in the treatment of melanoma: Best practices and future directions. Am J Clin Dermatol 21: 821-832. https://doi.org/10.1007/s40257-020-00554-8

Ledford H (2020) CRISPR treatment inserted directly into the body for first time. Nature 579: 185. https://doi.org/10.1038/d41586020-00655-8

Li C, Samulski RJ (2020) Engineering adeno-associated virus vectors for gene therapy. Nat Rev Genet 21: 255-272. https://doi. org/10.1038/s41576-019-0205-4

Liu Q, Muruve DA (2003) Molecular basis of the inflammatory response to adenovirus vectors. Gene Ther 10: 935-940. https://doi. org/10.1038/sj.gt.3302036

Loboda A, Dulak J (2020) Muscle and cardiac therapeutic strategies for Duchenne muscular dystrophy: past, present, and future. Pharmacol Rep 72: 1227-1263. https://doi.org/10.1007/s43440-020-00134-x

Maguire AM, Bennett J, Aleman EM, Leroy BP, Aleman TS (2021) Clinical perspective: Treating RPE65-associated retinal dystrophy. Mol Ther 29: 442-463. https://doi.org/10.1016/j.ymthe.2020.11.029

Mamcarz E, Zhou S, Lockey T, Abdelsamed H, Cross SJ, Kang G, Ma Z, Condori J, Dowdy J, Triplett B, Li C, Maron G, Aldave Becerra JC, Church JA, Dokmeci E, Love JT, da Matta Ain AC, van der Watt $H$, Tang X, Janssen W, Ryu BY, De Ravin SS, Weiss MJ, Youngblood B, Long-Boyle JR, Gottschalk S, Meagher MM, Malech HL, Puck JM, Cowan MJ, Sorrentino BP (2019) Lentiviral gene therapy combined with low-dose busulfan in infants with SCID-X1. $N$ Engl J Med 380: 1525-1534. https://doi.org/10.1056/ NEJMoa1815408

Mandai M, Watanabe A, Kurimoto Y, Hirami Y, Morinaga C, Daimon T, Fujihara M, Akimaru H, Sakai N, Shibata Y, Terada M, Nomiva Y, Tanishima S, Nakamura M, Kamao H, Sugita S, Onishi A, Ito T, Fujita K, Kawamata S, Go MJ, Shinohara C, Hata K-I, Sawada M, Yamamoto M, Ohta S, Ohara Y, Yoshida K, Kuwahara J, Kitano Y, Amano N, Umekage M, Kitaoka F, Tanaka A, Okada C, Takasu N, Ogawa S, Yamanaka S, Takahashi M (2017) Autologous induced stem-cell-derived retinal cells for macular degeneration. $N$ Engl J Med 376: 1038-1046. https://doi.org/10.1056/NEJMoa1608368

Manno CS, Pierce GF, Arruda VR, Glader B, Ragni M, Rasko JJ, Rasko J, Ozelo MC, Hoots K, Blatt P, Konkle B, Dake M, Kaye R, Razavi M, Zajko A, Zehnder I, Rustagi PK, Nakai H, Chew A, Leonard D, Wright JF, Lessard RR, Sommer JM, Tigges M, Sabatino D, Luk A, Jiang H, Mingozzi F, Couto L, Ertl HC, High KA,
Kay MA (2006) Successful transduction of liver in hemophilia by AAV-Factor IX and limitations imposed by the host immune response. Nat Med 12: 342-347. https://doi.org/10.1038/nm1358

Massaro G, Geard AF, Liu W, Coombe-Tennant O, Waddington SN, Baruteau J, Gissen P, Rahim AA (2021) Gene therapy for lysosomal storage disorders: ongoing studies and clinical development. Biomolecules 11: 611. https://doi.org/10.3390/biom11040611

Mavilio F, Pellegrini G, Ferrari S, Di Nunzio F, Di Iorio E, Recchia A, Maruggi G, Ferrari G, Provasi E, Bonini C, Capurro S, Conti A, Magnoni C, Giannetti A, De Luca M (2006) Correction of junctional epidermolysis bullosa by transplantation of genetically modified epidermal stem cells. Nat Med 12: 1397-1402. https://doi. org $/ 10.1038 / \mathrm{nm} 1504$

Mendell JR, Al-Zaidy S, Shell R, Arnold WD, Rodino-Klapac LR, Prior TW, Lowes L, Alfano L, Berry K, Church K, Kissel JT, Nagendran S, L'Italien J, Sproule DM, Wells C, Cardenas JA, Heitzer MD, Kaspar A, Corcoran S, Braun L, Likhite S, Miranda C, Meyer K, Foust KD, Burghes AHM, Kaspar BK (2017) Single-dose gene-replacement therapy for spinal muscular atrophy. N Engl J Med 377: 1713-1722. https://doi.org/10.1056/NEJMoa1706198

Mendell JR, Al-Zaidy SA, Lehman KJ, McColly M, Lowes LP, Alfano LN, Reash NF, Iammarino MA, Church KR, Kleyn A, Meriggioli MN, Shell R (2021a) Five-year extension results of the phase 1 START trial of onasemnogene abeparvovec in spinal muscular atrophy. JAMA Neurol 78: 834-841. https://doi.org/10.1001/jamaneurol.2021.1272

Mendell JR, Al-Zaidy SA, Rodino-Klapac LR, Goodspeed K, Gray SJ, Kay CN, Boye SL, Boye SE, George LA, Salabarria S, Corti M, Byrne BJ, Tremblay JP (2021b) Current clinical applications of in vivo gene therapy with AAVs. Mol Ther 29: 464-488. https://doi. org/10.1016/j.ymthe.2020.12.007

Milone MC, O’Doherty U (2018) Clinical use of lentiviral vectors. Leukemia 32: 1529-1541. https://doi.org/10.1038/s41375-018-0106-0

Montini E, Cesana D, Schmidt M, Sanvito F, Bartholomae CC, Ranzani M, Benedicenti F, Sergi LS, Ambrosi A, Ponzoni M, Doglioni C, Di Serio C, von Kalle C, Naldini L (2009) The genotoxic potential of retroviral vectors is strongly modulated by vector design and integration site selection in a mouse model of HSC gene therapy. $J$ Clin Invest 119: 964-975. https://doi.org/10.1172/JCI37630

Munshi NC, Anderson LD, Shah N, Madduri D, Berdeja J, Lonial S, Raje N, Lin Y, Siegel D, Oriol A, Moreau P, Yakoub-Agha I, Delforge M, Cavo M, Einsele H, Goldschmidt H, Weisel K, Rambaldi A, Reece D, Petrocca F, Massaro M, Connarn JN, Kaiser S, Patel P, Huang L, Campbell TB, Hege K, San-Miguel J (2021) Idecabtagene vicleucel in relapsed and refractory multiple myeloma. $N$ Engl J Med 384: 705-716. https://doi.org/10.1056/NEJMoa2024850

Muul LM, Tuschong LM, Soenen SL, Jagadeesh GJ, Ramsey WJ, Long Z, Carter CS, Garabedian EK, Alleyne M, Brown M, Bernstein W, Schurman SH, Fleisher TA, Leitman SF, Dunbar CE, Blaese RM, Candotti F (2003) Persistence and expression of the adenosine deaminase gene for 12 years and immune reaction to gene transfer components: long-term results of the first clinical gene therapy trial. Blood 101: 2563-2569. https://doi.org/10.1182/blood-2002-09-2800

Naldini L (2019) Genetic engineering of hematopoiesis: current stage of clinical translation and future perspectives. EMBO Mol Med 11: e9958. https://doi.org/10.15252/emmm.201809958

Nathwani AC, Reiss UM, Tuddenham EGD, Rosales C, Chowdary P, McIntosh J, Della Peruta M, Lheriteau E, Patel N, Raj D, Riddell A, Pie J, Rangarajan S, Bevan D, Recht M, Shen Y-M, Halka KG, Basner-Tschakarjan E, Mingozzi F, High KA, Allay J, Kay MA, Ng CYC, Zhou J, Cancio M, Morton CL, Gray JT, Srivastava D, Nienhuis AW, Davidoff AM (2014) Long-term safety and efficacy of factor IX gene therapy in hemophilia B. N Engl J Med 371: 1994 2004. https://doi.org/10.1056/NEJMoa1407309

Nathwani AC, Tuddenham EGD, Rangarajan S, Rosales C, McIntosh J, Linch DC, Chowdary P, Riddell A, Pie AJ, Harrington C, O'Beirne J, Smith K, Pasi J, Glader B, Rustagi P, Ng CYC, Kay MA, Zhou J, Spence Y, Morton CL, Allay J, Coleman J, Sleep S, Cunningham JM, Srivastava D, Basner-Tschakarjan E, Mingozzi F, High KA, Gray JT, Reiss UM, Nienhuis AW, Davidoff AM (2011) Adenovirus-associated virus vector-mediated gene transfer in hemophilia B. N Engl J Med 365: 2357-2365. https://doi.org/10.1056/ NEJMoa1108046

Podhajska AJ, Szybalski W (1985) Conversion of the FokI endonuclease to a universal restriction enzyme: cleavage of phage M13mp7 DNA at predetermined sites. Gene 40: 175-182. https://doi. org/10.1016/0378-1119(85)90040-x

Poletti V, Biffi A (2019) Gene-based approaches to inherited neurometabolic diseases. Hum Gene Ther 30: 1222-1235. https://doi. org/10.1089/hum.2019.190

Ramos DM, d'Ydewalle C, Gabbeta V, Dakka A, Klein SK, Norris DA, Matson J, Taylor SJ, Zaworski PG, Prior TW, Snyder PJ, Valdivia D, Hatem CL, Waters I, Gupte N, Swoboda KJ, Rigo F, Bennett CF, Naryshkin N, Paushkin S, Crawford TO, Sumner CJ (2019) Age-dependent SMN expression in disease-relevant tissue 
and implications for SMA treatment. I Clin Invest 129: 4817-4831. https://doi.org/10.1172/JCI124120

Rangarajan S, Walsh L, Lester W, Perry D, Madan B, Laffan M, Yu H, Vettermann C, Pierce GF, Wong WY, Pasi KJ (2017) AAV5factor VIII gene transfer in severe hemophilia A. N Engl J Med 377: 2519-2530. https://doi.org/10.1056/NEJMoa1708483

Rosenberg SA, Aebersold P, Cornetta K, Kasid A, Morgan RA, Moen R, Karson EM, Lotze MT, Yang JC, Topalian SL (1990) Gene transfer into humans--immunotherapy of patients with advanced melanoma, using tumor-infiltrating lymphocytes modified by retroviral gene transduction. $N$ Engl J Med 323: 570-578. https://doi, org/10.1056/NEJM199008303230904

Sadarangani M, Marchant A, Kollmann TR (2021) Immunological mechanisms of vaccine-induced protection against COVID-19 in humans. Nat Rev Immunol https://doi.org/10.1038/s41577-02100578-Z

Schwartz SD, Regillo CD, Lam BL, Eliott D, Rosenfeld PJ, Gregori NZ, Hubschman J-P, Davis JL, Heilwell G, Spirn M, Maguire J, Gay R, Bateman J, Ostrick RM, Morris D, Vincent M, Anglade E, Del Priore LV, Lanza R (2015) Human embryonic stem cell-derived retinal pigment epithelium in patients with age-related macular degeneration and Stargardt's macular dystrophy: follow-up of two open-label phase 1/2 studies. Lancet 385: 509-516. https://doi. org/10.1016/S0140-6736(14)61376-3

Senzer N, Nemunaitis J (2009) A review of contusugene ladenovec (Advexin) p53 therapy. Curr Opin Mol Ther 11: 54-61

Sessa M, Lorioli L, Fumagalli F, Acquati S, Redaelli D, Baldoli C, Canale S, Lopez ID, Morena F, Calabria A, Fiori R, Silvani P, Rancoita PMV, Gabaldo M, Benedicenti F, Antonioli G, Assanelli A, Cicalese MP, Del Carro U, Sora MGN, Martino S, Quattrini A, Montini E, Di Serio C, Ciceri F, Roncarolo MG, Aiuti A, Naldini L, Biffi A (2016) Lentiviral haemopoietic stem-cell gene therapy in early-onset metachromatic leukodystrophy: an ad-hoc analysis of a non-randomised, open-label, phase 1/2 trial. Lancet 388: 476-487. https:// doi.org/10.1016/S0140-6736(16)30374-9

Shaw KL, Garabedian E, Mishra S, Barman P, Davila A, Carbonaro D, Shupien S, Silvin C, Geiger S, Nowicki B, Smogorzewska EM, Brown B, Wang X, de Oliveira S, Choi Y, Ikeda A, Terrazas D, Fu P-Y, Yu A, Fernandez BC, Cooper AR, Engel B, Podsakoff G, Balamurugan A, Anderson S, Muul L, Jagadeesh GJ, Kapoor N, Tse J, Moore TB, Purdy K, Rishi R, Mohan K, Skoda-Smith S, Buchbinder D, Abraham RS, Scharenberg A, Yang OO, Cornetta K, Gjertson D, Hershfield M, Sokolic R, Candotti F, Kohn DB (2017) Clinical efficacy of gene-modified stem cells in adenosine deaminase-deficient immunodeficiency. J Clin Invest 127: 1689-1699. https://doi.org/10.1172/JCI90367

Sheikh S, Ernst D, Keating A (2021) Prodrugs and prodrug-activated systems in gene therapy. Mol Ther 29: 1716-1728. https://doi. org/10.1016/j.ymthe.2021.04.006

Staal FJT, Aiuti A, Cavazzana M (2019) Autologous stem-cell-based gene therapy for inherited disorders: State of the art and perspectives. Front Pediatr 7: 443. https://doi.org/10.3389/fped.2019.00443

Stein S, Ott MG, Schultze-Strasser S, Jauch A, Burwinkel B, Kinner A, Schmidt M, Krämer A, Schwäble J, Glimm H, Koehl U, Preiss C, Ball C, Martin H, Göhring G, Schwarzwaelder K, Hofmann W-K, Karakaya K, Tchatchou S, Yang R, Reinecke P, Kühlcke K, Schlegelberger B, Thrasher AJ, Hoelzer D, Seger R, von Kalle C, Grez M (2010) Genomic instability and myelodysplasia with monosomy 7 consequent to EVI1 activation after gene therapy for chronic granulomatous disease. Nat Med 16: 198-204. https://doi. org/10.1038/nm.2088

Sun J, Roy S (2021) Gene-based therapies for neurodegenerative diseases. Nat Neurosci 24: 297-311. https://doi.org/10.1038/s41593020-00778-1

Szybalska EH, Szybalski W (1962) Genetics of human cell line. IV. DNA-mediated heritable transformation of a biochemical trait. Proc Natl Acad Sci U S A 48: 2026-2034. https://doi.org/10.1073/ pnas.48.12.2026

Szybalski W (2013) The 50th anniversary of gene therapy: beginnings and present realities. Gene 525: 151-154. https://doi.org/10.1016/j. gene.2013.03.006

Tebas P, Jadlowsky JK, Shaw PA, Tian L, Esparza E, Brennan AL, Kim S, Naing SY, Richardson MW, Vogel AN, Maldini CR, Kong H, Liu X, Lacey SF, Bauer AM, Mampe F, Richman LP, Lee G,
Ando D, Levine BL, Porter DL, Zhao Y, Siegel DL, Bar KJ, June CH, Riley JL (2021) CCR5-edited CD4+ T cells augment HIV-specific immunity to enable post-rebound control of HIV replication. J Clin Invest 131. https:/ / doi.org/10.1172/JCI144486

Tebas P, Stein D, Tang WW, Frank I, Wang SQ, Lee G, Spratt SK, Surosky RT, Giedlin MA, Nichol G, Holmes MC, Gregory PD, Ando DG, Kalos M, Collman RG, Binder-Scholl G, Plesa G, Hwang W-T, Levine BL, June CH (2014) Gene editing of CCR5 in autologous CD4 $\mathrm{T}$ cells of persons infected with HIV. N Engl J Med 370: 901-910. https://doi.org/10.1056/NEJMoa1300662

Thompson AA, Walters MC, Kwiatkowski J, Rasko JEJ, Ribeil J-A, Hongeng S, Magrin E, Schiller GJ, Payen E, Semeraro M, Moshous D, Lefrere F, Puy H, Bourget P, Magnani A, Caccavelli L, Diana J-S, Suarez F, Monpoux F, Brousse V, Poirot C, Brouzes C, Meritet J-F, Pondarré C, Beuzard Y, Chrétien S, Lefebvre T., Teachey DT, Anurathapan U, Ho PJ, von Kalle C, Kletzel M, Vichinsky E, Soni S, Veres G, Negre O, Ross RW, Davidson D, Petrusich A, Sandler L, Asmal M, Hermine O, De Montalembert M, Hacein-Bey-Abina S, Blanche S, Leboulch P, Cavazzana M (2018) Gene therapy in patients with transfusion-dependent $\beta$-thalassemia. N Engl J Med 378: 1479-1493. https://doi.org/10.1056/NEJMoa1705342

Trono D (2012) Gene therapy: too much splice can spoil the dish. I Clin Invest 122: 1600-1602. https://doi.org/10.1172/JCI63066

Tucci F, Scaramuzza S, Aiuti A, Mortellaro A (2021) Update on clinical ex vivo hematopoietic stem cell gene therapy for inherited monogenic diseases. Mol Ther 29: 489-504. https://doi.org/10.1016/j. ymthe.2020.11.020

Urits I, Swanson D, Swett MC, Patel A, Berardino K, Amgalan A, Berger AA, Kassem H, Kaye AD, Viswanath O (2020) A Review of Patisiran (ONPATTROß) for the treatment of polyneuropathy in people with hereditary transthyretin amyloidosis. Neurol Ther 9: 301-315. https://doi.org/10.1007/s40120-020-00208-1

Urnov FD, Rebar EJ, Holmes MC, Zhang HS, Gregory PD (2010) Genome editing with engineered zinc finger nucleases. Nat Rev Genet 11: 636-646. https://doi.org/10.1038/nrg2842

Westphal M, Ylä-Herttuala S, Martin J, Warnke P, Menei P, Eckland D, Kinley J, Kay R, Ram Z, ASPECT Study Group (2013) Adenovirus-mediated gene therapy with sitimagene ceradenovec followed by intravenous ganciclovir for patients with operable high-grade glioma (ASPECT): a randomised, open-label, phase 3 trial. Lancet Oncol 14: 823-833. https://doi.org/10.1016/S1470-2045(13)70274-2

Winkle M, El-Daly SM, Fabbri M, Calin GA (2021) Noncoding RNA therapeutics - challenges and potential solutions. Nat Rev Drug Discov 20: 629-651. https://doi.org/10.1038/s41573-021-00219-z

Wirth B (2021) Spinal Muscular Atrophy: In the Challenge Lies a Solution. Trends Neurosci. 44: 306-322. https://doi.org/10.1016/j. tins.2020.11.009

Wirth B, Karakaya M, Kye MJ, Mendoza-Ferreira N (2020) Twentyfive years of spinal muscular atrophy research: From phenotype to genotype to therapy, and what comes next. Annu Rev Genomics Hum Genet 21: 231-261. https://doi.org/10.1146/annurevgenom-102319-103602

Wirth T, Parker N, Ylä-Herttuala S (2013) History of gene therapy. Gene 525: 162-169. https://doi.org/10.1016/j.gene.2013.03.137

Wood AJ, Lo T-W, Zeitler B, Pickle CS, Ralston EJ, Lee AH, Amora R, Miller JC, Leung E, Meng X, Zhang L, Rebar EJ, Gregory PD, Unnov FD, Meyer BJ (2011) Targeted genome editing across species using ZFNs and TALENs. Science 333: 307. https://doi. org/10.1126/science. 1207773

Wu X, Li Y, Crise B, Burgess SM (2003) Transcription start regions in the human genome are favored targets for MLV integration. Science 300: 1749-1751. https://doi.org/10.1126/science.1083413

Ylä-Herttuala S (2012) Endgame: glybera finally recommended for approval as the first gene therapy drug in the European union. Mol Ther 20: 1831-1832. https://doi.org/10.1038/mt.2012.194

Zeng J, Wu Y, Ren C, Bonanno J, Shen AH, Shea D, Gehrke JM, Clement K, Luk K, Yao Q, Kim R, Wolfe SA, Manis JP, Pinello L, Joung JK, Bauer DE (2020) Therapeutic base editing of human hematopoietic stem cells. Nat Med 26: 535-541. https://doi. org/10.1038/s41591-020-0790-y

Zou S, Glynn S, Kuritzkes D, Shah M, Cook N, Berliner N, NHLBI AIDS Blood Session Working Group (2013) Hematopoietic cell transplantation and HIV cure: where we are and what next? Blood 122: 3111-3115. https://doi.org/10.1182/blood-2013-07-518316 